\title{
Defective chemoattractant-induced calcium signalling in S100A9 null neutrophils
}

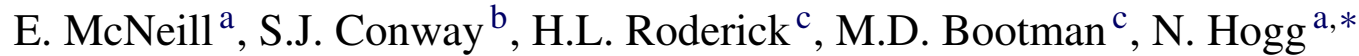 \\ ${ }^{a}$ Leukocyte Adhesion Laboratory, Cancer Research UK London Research Institute (CRUK LRI), 44 Lincoln's Inn Fields, London WC2A 3PX, UK \\ ${ }^{\mathrm{b}}$ Department of Chemistry, School of Chemistry, University of St Andrews, St Andrews KY16 9ST, UK \\ ${ }^{\mathrm{c}}$ Laboratory of Molecular Signalling, The Babraham Institute, Babraham, Cambridge CB2 4AT, UK
}

Received 14 March 2006; received in revised form 14 May 2006; accepted 18 May 2006

Available online 30 June 2006

\begin{abstract}
The S100 family member S100A9 and its heterodimeric partner, S100A8, are cytosolic $\mathrm{Ca}^{2+}$ binding proteins abundantly expressed in neutrophils. To understand the role of this EF-hand-containing complex in $\mathrm{Ca}^{2+}$ signalling, neutrophils from $\mathrm{S} 100 \mathrm{~A} 9$ null mice were investigated. There was no role for the complex in buffering acute cytosolic $\mathrm{Ca}^{2+}$ elevations. However, $\mathrm{Ca}^{2+}$ responses to inflammatory agents such as chemokines MIP-2 and KC and other agonists are altered. For S100A9 null neutrophils, signalling at the level of G proteins is normal, as is release of $\mathrm{Ca}^{2+}$ from the $\mathrm{IP}_{3}$ receptor-gated intracellular stores. However MIP-2 and FMLP signalling in S100A9 null neutrophils was less susceptible than wildtype to PLC $\beta$ inhibition, revealing dis-regulation of the signalling pathway at this level. Downstream of PLC $\beta$, there was reduced intracellular $\mathrm{Ca}^{2+}$ release induced by sub-maximal levels of chemokines. Conversely the response to FMLP was uncompromised, demonstrating different regulation compared to MIP-2 stimulation. Study of the activity of PLC product DAG revealed that chemokine-induced signalling was susceptible to inhibition by elevated DAG with S100A9 null cells showing enhanced inhibition by DAG. This study defines a lesion in S100A9 null neutrophils associated with inflammatory agonist-induced $\mathrm{IP}_{3}$-mediated $\mathrm{Ca}^{2+}$ release that is manifested at the level of PLC $\beta$.
\end{abstract}

(C) 2006 Elsevier Ltd. All rights reserved.

Keywords: S100; Knockout; Neutrophil; Chemokine; Calcium

\section{Introduction}

S100A8 and S100A9 are low molecular weight $\mathrm{Ca}^{2+}$ binding proteins of the EF-hand type that are part of a family of approximately 19 members [1-4]. Uncharacteristically for S100 proteins, S100A8/9 exists as a hetero-, rather than homodimer [5,6]. These members of the S100 family are

Abbreviations: 2-APB, 2-aminoethyldiphenyl borate; AM, acetoxymethyl ester; BIM, bisindolylmaleimide; $\mathrm{CaBP}$, calcium binding protein; DAG, diacylglycerol; ER, endosplasmic reticulum; FMLP, $N$-formylmethionyl-leucyl-phenylalanine; HBSS, Hanks buffered saline solution; $\mathrm{IP}_{3}$, inositol-1,4,5-triphosphate; mAb, monoclonal antibody; MIP, macrophage inflammatory protein; OAG, 1-oleoyl-2-acyl-sn-glycerol; PAF, platelet activating factor; PKC, protein kinase C; PLC, phospholipase C; PTX, pertussis toxin; SOCE, store operated calcium entry

* Corresponding author. Tel.: +44 207269 3255; fax: +44 2072693093.

E-mail address: Nancy.Hogg@ cancer.org.uk (N. Hogg). primarily expressed by neutrophils and monocytes [4]. In human neutrophils, the heterodimer constitutes an abundant $40 \%$ of the cytosolic protein [5] and, similarly, in murine neutrophils, the S100A9 protein alone represents $10-20 \%$ of cytosolic protein [7].

In resting neutrophils the S100A8/9 complex is present in the cytosol but treatment with stimuli such as zymosan cause the complex to move to the membrane $[8,9]$ possibly into detergent insoluble lipid rafts [10]. Alternatively, in human monocytes, the $\mathrm{Ca}^{2+}$ ionophore, ionomycin, causes the heterodimer to translocate from the cytosol to the cytoskeletal and vimentin-containing structures $[11,12]$. A fraction of S100A8/9 becomes phosphorylated following exposure to agonists [13] and, in monocytes, there is preferential translocation of phosphorylated S100A8/9 to the membrane and cytoskeletal fraction [14]. An association of S100A8/9 with the microtubule system and secretion of the 
complex in a tubulin-dependent manner has been reported [15].

S100 proteins are unusual in having both intracellular and extracellular roles assigned to them. Neutrophil chemoattractant activity has been attributed to murine S100A8 [16] and to human S100A8 and S100A9 proteins [17], although these findings have been questioned by others [18]. The association of S100A8/9 with the vascular cell surface in proximity to extravasating leukocytes is suggestive of involvement in the process of leukocyte trafficking [1]. S100A8/9 binds to cell surface heparan-sulphate glycosaminoglycans on endothelial cells, thereby being appropriately positioned to affect leukocyte recruitment or another extracellular role [19]. A carboxylated $\mathrm{N}$-glycan motif present on the surface of endothelial cells also binds S100A8/9 and a mAb specific for this $\mathrm{N}$-glycan reduced the recruitment of neutrophils in vivo providing further suggestive evidence of a role for these proteins in leukocyte trafficking [20,21]. Treatment of endothelial cells with recombinant S100A8/9 has also been reported to cause a decrease in monolayer integrity and expression of pro-inflammatory mediators [22].

The initial characterization of the S100A9 null mice indicated that the protein is dispensable for life span, morphological features and many functions of neutrophils and monocytes $[23,24]$. The most obvious difference between the S100A9 null and wildtype neutrophils is the absence of S100A8 implying that it is unstable without its S100A9 partner as suggested previously [25]. Although many neutrophil functions appear unaffected in the S100A9 null mice, the S100A9 null neutrophils did exhibit reduced $\mathrm{Ca}^{2+}$ signalling to submaximal levels of stimulation to the chemokine MIP-2 [23].

Proteins of the S100 family have been considered to be $\mathrm{Ca}^{2+}$ buffering proteins but may act as $\mathrm{Ca}^{2+}$ sensors. Upon $\mathrm{Ca}^{2+}$ binding, S100 dimers undergo a conformational change exposing a hydrophobic interaction surface deemed to mediate their interaction with target proteins (reviewed in [26]). Other S100 proteins have been highlighted as having a role in $\mathrm{Ca}^{2+}$ homeostasis. S100A1 null mice have a lesion in the $\mathrm{Ca}^{2+}$ response to $\beta$-adrenergic stimulation in cardiomyocytes and show lack of compensation for an increased cardiac workload in a model of acute hemodynamic stress [27]. Over-expression of S100A1 causes increased $\mathrm{Ca}^{2+}$ loading of the sarcoplasmic reticulum in cardiomyocytes [28]. Finally $\mathrm{S} 100 \mathrm{~B}$ null mice show enhanced $\mathrm{Ca}^{2+}$ transients in response to caffeine in astrocyte cell cultures [29].

Neutrophil functions can be regulated by $\mathrm{Ca}^{2+}$ and chemoattractants represent well-defined stimuli of $\mathrm{Ca}^{2+}$ signalling in neutrophils (reviewed in [30,31]). However, neither the details of chemoattractant-induced signalling pathway(s) leading to $\mathrm{Ca}^{2+}$ increases nor the functional outcomes are fully defined $[32,33]$. In this study, the basic $\mathrm{Ca}^{2+}$ homeostasis and chemoattractant-induced $\mathrm{Ca}^{2+}$ signals in neutrophils are examined in an effort to understand the $\mathrm{Ca}^{2+}$ signalling lesion in the S100A9 null neutrophils. We find that S100A8/9 does not act as a major $\mathrm{Ca}^{2+}$ buffer, but $\mathrm{Ca}^{2+}$ signalling is dis-regulated at the level of PLC $\beta$ in response to chemoattrac- tants. For a number of chemokines and other chemoattactants, but not FMLP, this dis-regulation reveals a downstream role for PLC product, DAG, which has a suppressive effect at enhanced levels on $\mathrm{Ca}^{2+}$ release from $\mathrm{IP}_{3}$ receptor-regulated $\mathrm{Ca}^{2+}$ stores.

\section{Experimental}

\subsection{Antibodies and other reagents}

Rabbit polyclonal anti-PLC $\beta 2$ (Santa Cruz Biotech.), anti-PLC $\beta 3$ (Cell Signalling Tech.), and mouse anti-IP ${ }_{3} R$ (Chemicon Intl.) were used. The rabbit polyclonal antiCXCR2 antibody was a kind gift from R.M. Strieter (UCLA). Goat anti-rabbit immunoglobulin-horseradish peroxidase conjugate and goat anti-mouse immunoglobulinhorseradish peroxidase conjugate were both from Dako Ltd. Alexa 488-conjugated donkey anti-goat polyclonal and Alexa 633-conjugated goat anti-rat were obtained from Invitrogen/Molecular Probes. MAb 7/4 was obtained from Caltag Medsystems and anti-Mac-1 and Ly-6G mAbs were obtained from BD Biosciences/Pharmingen.

The following stimulants were used: FMLP (Sigma), ionomycin (Calbiochem), thapsigargin (Calbiochem), chemokines KC, MIP-1 $\alpha$, and MIP-2 (all Peprotech EC), $\mathrm{PAF}, \mathrm{C} 5 \mathrm{a}$ and $\mathrm{G}$ protein activator $\mathrm{ALF}_{4}{ }^{-}$(all Sigma). The following inhibitors were used: $\mathrm{IP}_{3}$ receptor inhibitor 2-aminoethoxydiphenyl borate (2-APB), protein kinase $\mathrm{C}$ inhibitors (BIM and Calphostin C), DAG kinase inhibitor II (R59949), DAG mimetic olelylacylglycerol (OAG), pertussis toxin (PTX), DAG lipase inhibitor (RHC 80267), PLC inhibitor (U73122) and control compound (U73343) (all Calbiochem). All reagents were titrated and used at maximal concentrations with due consideration of neutrophil viability.

A membrane-permeant derivative of $\mathrm{IP}_{3}, \mathrm{IP}_{3}-\mathrm{AM}$, was used to stimulate the $\mathrm{IP}_{3}$ receptors directly. $\mathrm{IP}_{3}-\mathrm{AM}$ is a form of $\mathrm{IP}_{3}$ in which the phosphate groups are protected with the lipophilic butyryloxymethyl groups. These groups allow the ester to diffuse across the cell membrane but once in the cell are removed by esterases revealing $\mathrm{IP}_{3}$. The $\mathrm{IP}_{3}-\mathrm{AM}$ ester was synthesised in a manner similar to that reported for PtdIns(4,5)P2 [34] combined with the approach reported by Tsien and co-workers [35].

\subsection{Animal husbandry}

S100A9 null mice were generated as published previously [23]. Wildtype and S100A9 null mice from the same backcross generation (7-9) were used until backcross generation 10 when in-house C57BL/6J control mice were used. Mice were maintained in specific pathogen-free conditions in accordance with UK Home Office guidelines.

\subsection{Murine bone marrow leukocytes}

Murine bone marrow leukocytes were harvested by flushing both femurs and tibiae with Hank's buffered salt solution 
(HBSS: $0.4 \mathrm{~g} / \mathrm{KCl}, 0.06 \mathrm{~g} / 1 \mathrm{KH}_{2} \mathrm{PO}_{4}, 8 \mathrm{~g} / \mathrm{l} \mathrm{NaCl}, 0.9 \mathrm{~g} / \mathrm{l}$ $\mathrm{Na}_{2} \mathrm{HPO}_{4}, 0.35 \mathrm{~g} / \mathrm{l} \mathrm{NaHCO} 3,1 \mathrm{~g} / \mathrm{l}$ D-glucose) (Gibco) containing $0.2 \%$ BSA (Sigma) using a needle and $2.5 \mathrm{ml}$ syringe. Cell clumps were dispersed by gentle agitation with a plastic pastette prior to passage through a $70 \mu \mathrm{M}$ cell strainer (Falcon). The cells were pelleted by centrifugation at $500 \times g$ for $5 \mathrm{~min}$ before resuspension in $1 \mathrm{ml}$ hypotonic red blood cell lysis solution $\left(0.144 \mathrm{M} \mathrm{NH}_{4} \mathrm{Cl} / 0.017 \mathrm{M}\right.$ Tris- $\mathrm{HCl}, \mathrm{pH}$ 7.2). Red blood cells were lysed at room temperature for $3 \mathrm{~min}$, then washed and resuspended in the relevant assay buffer.

\subsection{Chemotaxis}

Transwell (Corning) plates with a $3 \mu \mathrm{m}$ pore and $6.5 \mathrm{~mm}$ diameter insert were pre-incubated with chemotaxis buffer (HBSS containing $20 \mathrm{mM}$ HEPES, $1 \mathrm{mM} \mathrm{Ca}^{2+}, 1 \mathrm{mM} \mathrm{Mg}^{2+}$, $10 \mu \mathrm{M} \mathrm{Zn}{ }^{2+}$ and $0.1 \% \mathrm{BSA}$ ) at $37^{\circ} \mathrm{C}$ for $1 \mathrm{~h}$. About $600 \mu \mathrm{l}$ chemotaxis buffer containing various chemoattractant stimuli was placed in the plate wells. The Transwell insert was replaced and $5 \times 10^{6} / \mathrm{ml}$ bone marrow leukocytes in $100 \mu \mathrm{l}$ added. The plates were incubated for $2-4 \mathrm{~h}$ at $37{ }^{\circ} \mathrm{C}$ prior to removal of the insert and collection of the buffer from the lower chamber for analysis. The lower chambers were washed with ice-cold PBS/EDTA $(5 \mathrm{mM})$ twice and the additional recovered cells added to the buffer sample. The harvested cells were pelleted and stained in FACSwash as previously [36] to identify the neutrophils prior to absolute cell counting by flow cytometry.

\subsection{FACS staining of leukocyte suspensions}

$2 \times 10^{5}$ leukocytes were incubated in HBSS/0.2\% BSA containing saturating concentrations of CXCR2 antibody (1:50) on ice in the dark for $15 \mathrm{~min}$. The leukocytes were washed and the incubation procedure repeated with Alexa 488-conjugated donkey anti-goat antibody (1:100) followed by a directly conjugated myeloid cell detection cocktail (mAbs 7/4-PE and Ly-6G-FITC, 1:100 and 1:200, respectively) as previously described [36]. Analysis of cell surface receptor expression was carried out using a FACS-Calibur (Becton Dickinson).

For Mac-1 (CD11b/CD18) up-regulation experiments, bone marrow leukocytes were stimulated with chemokines as indicated for $30 \mathrm{~min}$ at $37^{\circ} \mathrm{C}$ prior to surface labelling. Mac-1 was detected using anti-Mac-1 mAb (1:100) followed by Alexa 633-conjugated goat anti-rat antibody (1:100) and the directly conjugated myeloid cell detection cocktail as above.

\subsection{Measurement of intracellular calcium concentration}

The use of a ratiometric $\mathrm{Ca}^{2+}$ indicator avoids problems of differential dye loading, as the change in $\mathrm{Ca}^{2+}$ concentration within each cell is measured as a ratio of the dye states, thus eliminating any differences in dye loading between samples. Bone marrow leukocytes were prepared in Flux buffer (HBSS, as before, supplemented with $1 \mathrm{mM} \mathrm{Ca}^{2+}$ and $0.5 \% \mathrm{BSA}$ ) and resuspended at $1 \times 10^{7} / \mathrm{ml}$ in $2.5 \mathrm{mM}$ Indo$1 \mathrm{AM} / 2.5 \%$ pluronic acid (both Molecular Probes). The cell suspension was incubated at $30^{\circ} \mathrm{C}$ for $1 \mathrm{~h}$ prior to washing in Flux buffer $\left(30^{\circ} \mathrm{C}\right)$. The cells were resuspended at $5 \times 10^{7} / \mathrm{ml}$ in Flux buffer containing mAbs 7/4-PE and Ly6G/Gr-1-FITC for $15 \mathrm{~min}$ at $30^{\circ} \mathrm{C}$. Cells were washed one final time and resuspended at $5 \times 10^{6} / \mathrm{ml}$ and maintained at $30^{\circ} \mathrm{C}$ prior to use. For inhibitor studies requiring preincubation, aliquots of cells were separated into tubes with the inhibitor indicated. Fluorescence was monitored using a BD LSR flow cytometer (FL-4 530/30 nm BF filter, FL5 424/44 filter, 510LP filter; BD Biosciences). Samples were read at a flow rate of 2000-3000 events/s and stimulants were added from $100 \times$ stock solutions at the indicated time points. Data was analysed using FlowJo software (TreeStar Inc.). Results are represented as the median Indo-1 ratio for 500-700 neutrophils/s.

\subsection{Western blotting}

Cells were suspended at $5 \times 10^{7} / \mathrm{ml}$ in ice-cold lysis buffer (50 mM Tris pH 8.0 containing 1\% Triton X-100 (Sigma), $2 \mathrm{mM}$ EDTA, $50 \mathrm{mM} \mathrm{NaCl}, 20 \mu \mathrm{g} / \mathrm{ml}$ PMSF (Sigma), $1 \mu \mathrm{g} / \mathrm{ml}$ aprotinin (Sigma)) and incubated for $30 \mathrm{~min}$ on ice with intermittent disruption with a $25 \mathrm{G}$ needle. The solution was then centrifuged in a microfuge to remove insoluble material and the supernatant decanted and subjected to $6 \%$ polyacrylamide gel electrophoresis followed by transfer to nitrocellulose.

Western blotting was performed with rabbit anti-PLC $\beta 2$ (1:100, Santa Cruz Biotech.), anti-PLC 33 (1:100, Cell Signalling Tech.) and mouse anti-IP ${ }_{3} \mathrm{R}$ (1:200, Chemicon Intl.) antibodies followed by goat anti-rabbit immunoglobulinhorseradish peroxidase conjugate (1:500) or goat anti-mouse immunoglobulin-horseradish peroxidase (1:500) conjugate (both Dako Ltd.).

\section{Results}

\subsection{Basic calcium signalling parameters in S100A9 null mice}

To assess whether the deletion of S100A8/9 had an impact on the $\mathrm{Ca}^{2+}$ signalling potential of the neutrophils, we first investigated $\mathrm{Ca}^{2+}$ homeostasis. Treatment of the S100A9 null and wildtype neutrophils with the $\mathrm{Ca}^{2+}$ ionophore ionomycin, which causes $\mathrm{Ca}^{2+}$ influx across the plasma membrane, or thapsigargin, which is an inhibitor of the $\mathrm{Ca}^{2+}$ ATPase on the $\mathrm{Ca}^{2+}$ stores within the endoplasmic reticulum, caused an identical sustained or transient rise respectively in intracellular $\mathrm{Ca}^{2+}$ in both wildtype and S100A9 null neutrophils (Fig. 1A and B). That the magnitude of the response is 
(A)

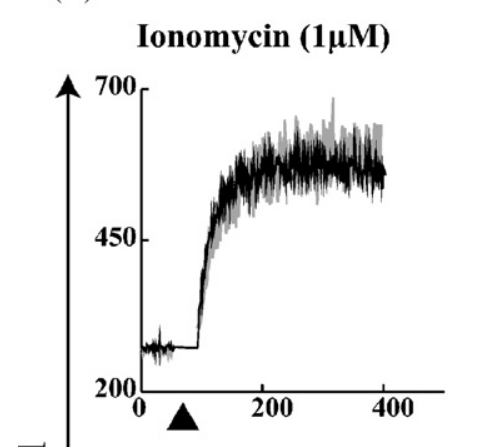

ํㅗㄹ

(B)

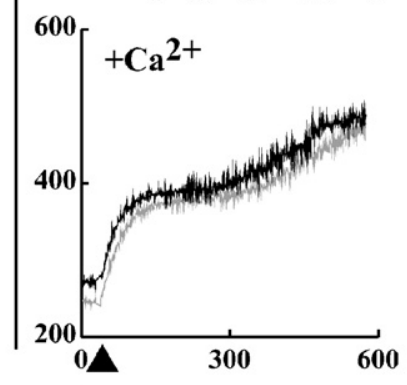

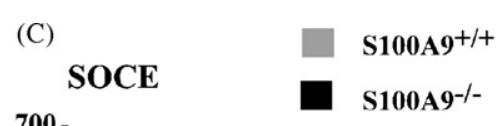

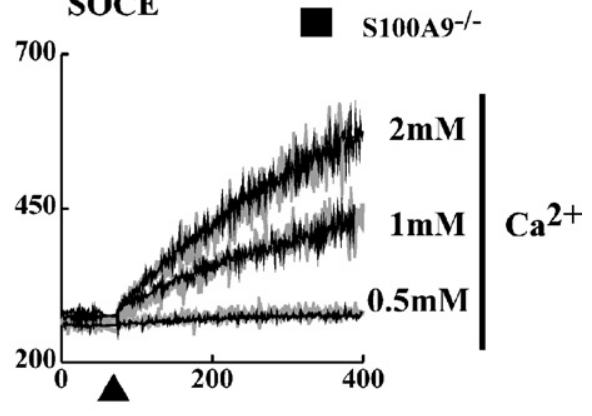

Time (s)

Fig. 1. Normal calcium homeostasis in S100A9 null neutrophils. Bone marrow leukocytes were loaded with Indo-1 and neutrophils were identified by labelling with mAbs 7/4 and Ly-6G. Intracellular $\mathrm{Ca}^{2+}$ concentration was monitored by flow cytometry and expressed as the arbitrary ratio of the Indo- 1 fluorescence at 424 and $530 \mathrm{~nm}$. Stimulants were applied at the indicated times $(\mathbf{\Lambda})$. The median response of neutrophil Indo- 1 ratio of $\approx 500-700$ events is plotted every second. The response to stimulation: (A) with $1 \mu \mathrm{M}$ ionomycin in the presence of extracellular $1 \mathrm{mM} \mathrm{Ca}^{2+}$; (B) with $5 \mu \mathrm{M}$ thapsigargin in the presence and absence of $1 \mathrm{mM}$ extracellular $\mathrm{Ca}^{2+}$ with absence generated by chelation with $4 \mathrm{mM}$ EGTA; (C) Store Operated $\mathrm{Ca}^{2+}$ Entry is examined by treatment of the neutrophils with $5 \mu \mathrm{M}$ thapsigargin in the absence of extracellular $\mathrm{Ca}^{2+}$, prior to add-back of $\mathrm{Ca}^{2+}$ at $0.5-2 \mathrm{mM}$. All data are representative of three or more independent experiments.

equivalent in both cell types implies that S100A8/9 is not acting as a major cellular $\mathrm{Ca}^{2+}$ buffer. When the cells were treated with thapsigargin in the presence of extracellular $\mathrm{Ca}^{2+}$, there was a biphasic increase in intracellular $\mathrm{Ca}^{2+}$ (Fig. 1B). The second phase of $\mathrm{Ca}^{2+}$ elevation is caused by opening of $\mathrm{Ca}^{2+}$ channels on the cell surface to allow re-filling of the emptying stores, termed Store Operated Calcium Entry (SOCE). SOCE can be assessed by treatment of the cells with thapsigargin in $\mathrm{Ca}^{2+}$ free buffer to fully empty the $\mathrm{Ca}^{2+}$ stores, then addition of $\mathrm{Ca}^{2+}$ to the buffer and observation of the profiles of the response. SOCE in the wildtype and S100A9 null cells is identical over a range of extracellular $\mathrm{Ca}^{2+}$ concentrations (Fig. 1C). No up-regulation of other proteins to compensate for the loss of the S100A8/9 heterodimer has been observed in the S100A9 null mice by 2D gel analysis of bone marrow cells [23]. In addition RT-PCR studies of the expression of other $\mathrm{S} 100$ proteins previously detected in leukocytes (S100A1, S100A4) revealed no compensatory increase in these family members (Supplementary Fig. 1). Therefore, there is no gross defect in $\mathrm{Ca}^{2+}$ homeostasis in the knockout cells. This function must be regulated by a means not involving S100A8/9.

\subsection{Defective calcium signalling to a range of, but not all, chemoattractants}

To test the ability of the neutrophils to mount a $\mathrm{Ca}^{2+}$ response to physiological stimuli, we examined the response to various chemoattractants, extending the previous observation that the S100A9 null neutrophils exhibited a defect in $\mathrm{Ca}^{2+}$ signalling to the chemokine MIP-2 [23]. The S100A9 null and wildtype neutrophils were stimulated with a titration of the CXC chemokine, MIP-2, in the presence of extracellular $\mathrm{Ca}^{2+}$. At higher levels of chemokine $(10 \mathrm{ng} / \mathrm{ml})$ there was no difference in the magnitude or duration of the response, but at lower levels of stimulation ( 1 and $0.3 \mathrm{ng} / \mathrm{ml}$ ), there was a decreased $\mathrm{Ca}^{2+}$ flux response in the S100A9 null neutrophils compared with the wildtype cells (Fig. 2A). A similar defect was observed upon stimulation of wildtype and knockout neutrophils with a second CXC chemokine $\mathrm{KC}, \mathrm{CC}$ chemokine MIP- $1 \alpha$ and the chemoattractants PAF and C5a (Fig. 2B). However, when neutrophils were exposed to FMLP, no defect in $\mathrm{Ca}^{2+}$ flux response was observed at any concentration of stimulus in the knockout cells (Fig. 2C). This data suggests that while the S100A9 
MIP-2
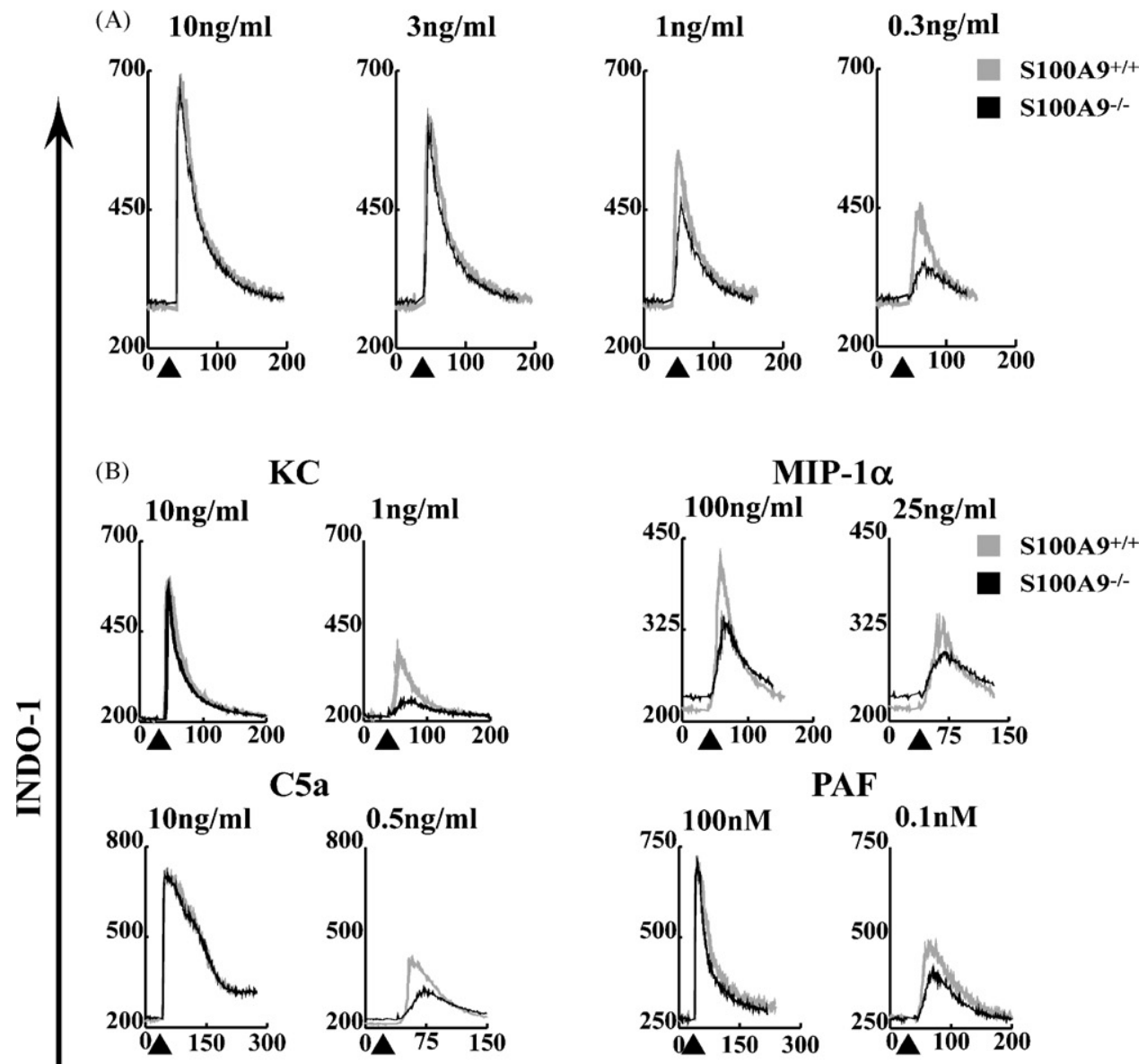

$\mathrm{KC}$
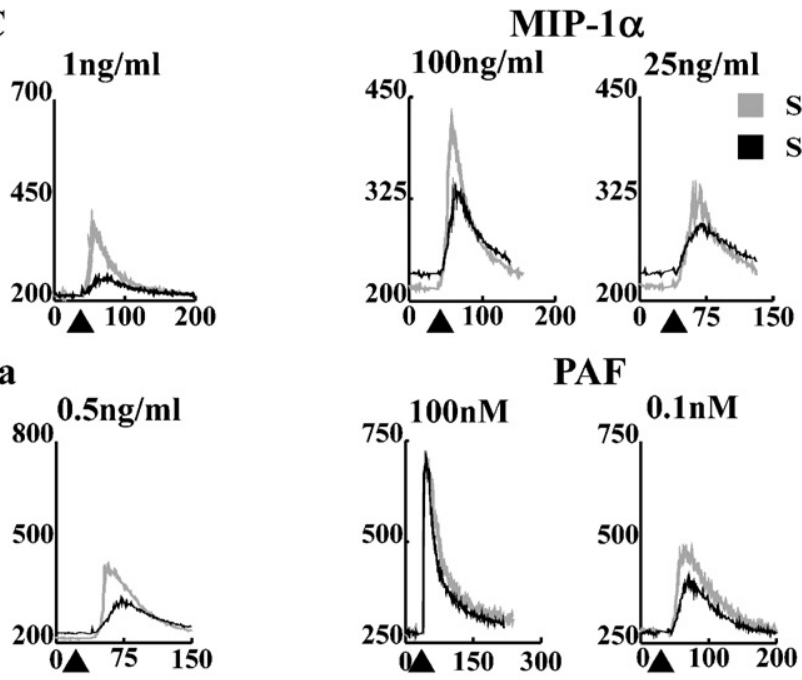

(C)

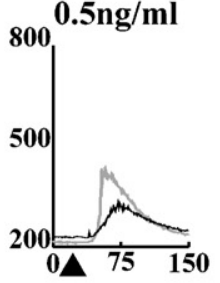

FMLP
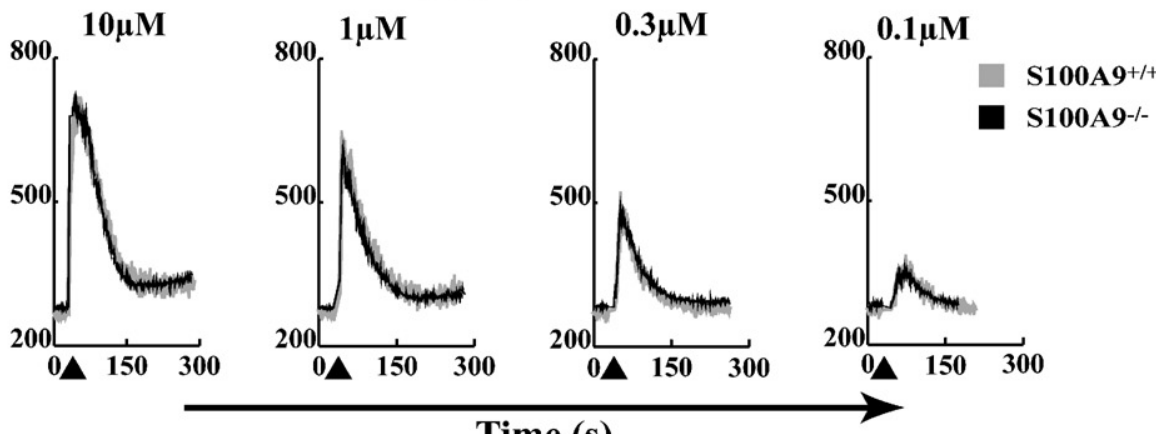

Fig. 2. Reduced calcium response to MIP-2 and other stimulants, but not to FMLP. (A) The $\mathrm{Ca}^{2+}$ response of neutrophils to the chemokine MIP-2 assessed as described in Fig. 1. (B) The $\mathrm{Ca}^{2+}$ response of neutrophils to the chemokines KC and MIP-1 $\alpha$ and chemoattractants, C5a and PAF. (C) The Ca ${ }^{2+}$ response of neutrophils to the chemoattractant FMLP. Data are representative of three independent experiments.

null neutrophils are compromised in their ability to produce a $\mathrm{Ca}^{2+}$ flux in response to a range of chemoattractant stimuli, this lesion is not generalised, but a problem with a specific signalling pathway that is used by some but not all chemoattractants. Alternatively a lesion in the signalling response to FMLP may be compensated for in S100A9 null neutrophils.

\subsection{The defect in calcium flux is not seen in other chemoattractant-induced neutrophil responses}

When neutrophils are stimulated with chemoattractant, as well as activation of a calcium flux, the cells are stimulated to chemotax towards the source of the stimulus and also to up-regulate the cell surface integrin Mac-1 (CD11b/CD18), 
a marker of cell activation. To examine further whether the observed defect in calcium signalling is a generalised decrease in responsiveness to chemoattractant, the ability of wildtype and S100A9 null neutrophils to perform these functions in response to MIP-2, KC and FMLP was examined.

No significant difference in in vitro chemotaxis in response to MIP-2, KC or FMLP was observed either at maximal or lower concentrations (correlating with the decreased calcium response in the S100A9 null mice) when wildtype and S100A9 null cells were compared (Fig. 3A). Similarly, when the levels of Mac-1 were evaluated following chemoattractant stimulation at maximal and sub-maximal levels of MIP-2 and FMLP, there was no reproducible difference in the ability of the S100A9 null and wildtype neutrophils to be activated (Fig. 3B). These data indicate that there is not a generalised shift in the responsiveness of the S100A9 null neutrophils to chemokine stimulation.

\subsection{The defect in calcium flux in the S100A9 null neutrophils is in intracellular calcium release}

To ascertain the source of $\mathrm{Ca}^{2+}$ for the response to the chemoattractants, neutrophils were stimulated in the presence or absence of extracellular $\mathrm{Ca}^{2+}$. When the neutrophils were stimulated with $20 \mathrm{ng} / \mathrm{ml}$ MIP-2, the response had a similar magnitude, but decreased duration in the absence compared to the presence of extracellular $\mathrm{Ca}^{2+}$ (Fig. 4). At a lower dose of MIP-2 $(1 \mathrm{ng} / \mathrm{ml})$, the response had a similar magnitude and duration both in the presence and absence of extracellular $\mathrm{Ca}^{2+}$. The majority of the $\mathrm{Ca}^{2+}$ contributing to this response therefore derives from the intracellular $\mathrm{Ca}^{2+}$ stores, with a minor component of extracellular $\mathrm{Ca}^{2+}$ entry contributing at high levels of chemokine. As the lesion in $\mathrm{Ca}^{2+}$ signalling is evident in both situations, it must be localised to the mechanisms of intracellular $\mathrm{Ca}^{2+}$ release. The response to FMLP relies on both intracellular and extracellular $\mathrm{Ca}^{2+}$, but the responses of S100A9 wildtype and null neutrophils are similar (Fig. 4). When the response to C5a was studied in a similar manner, the lesion was again found to be in intracellular $\mathrm{Ca}^{2+}$ release (data not shown). Thus, enhanced extracellular $\mathrm{Ca}^{2+}$ entry is not compensating for the intracellular $\mathrm{Ca}^{2+}$ release deficiency seen in the responses of the S100A9 null cells to the chemokines. As we were investigating primary neutrophils, to determine the characteristics of the compromised intracellular $\mathrm{Ca}^{2+}$ release pathway in S100A9 null mice, a feasible approach was to undertake a pharmacological study to compare the effect of different agents on the responses to the chemoattractants.

\subsection{The MIP-2- and FMLP-induced calcium fluxes occur via $G$ protein coupled pathway(s)}

This shift in the dose-response to chemoattractant could theoretically be explained by a lower expression of the receptor on the cell surface. However, expression of the CXCR2 receptor that binds $\mathrm{CXC}$ chemokines, MIP-2 and $\mathrm{KC}$, was at a similar level on both the wildtype and S100A9 null neutrophils (Fig. 5A). As MIP-1 $\alpha$, PAF and C5a all bind to distinct membrane receptors, it seemed unlikely that the lesion in $\mathrm{Ca}^{2+}$ signalling is at this level.

To test whether the $\mathrm{Ca}^{2+}$ flux responses occur normally via a $G$ protein coupled receptor pathway, the neutrophils were pre-incubated with pertussis toxin (PTX). The magnitude of the response to both MIP-2 and FMLP was reduced in the presence of PTX in both wildtype and S100A9 null cells (Fig. 5B). To confirm that the $\mathrm{Gi}$ protein coupled $\mathrm{Ca}^{2+}$ release pathways were broadly normal in these cells, they were treated with $\mathrm{AlF}^{-}$that non-specifically activates $\mathrm{G}$ proteins and again the response was similar in wildtype and S100A9 null cells (Fig. 5C).

\subsection{MIP-2- and FMLP-induced calcium fluxes are differentially inhibited by PLC inhibitor U73122 in wildtype and S100A9 null neutrophils}

The findings so far indicate that, in S100A9 neutrophils, the chemokine-induced $\mathrm{Ca}^{2+}$ flux operates normally at the level of the chemokine receptor. To ask whether the S100A9 null neutrophil lesion is due to an abnormality elsewhere in the signalling pathway, we next focussed on phospholipase $C$ (PLC $\beta$ ), which is activated by heterotrimeric $\mathrm{G}$ proteins. At $10 \mu \mathrm{M}$ U73122, the cell-permeable PLC inhibitor U73122 inhibited both MIP-2- and FMLP-induced $\mathrm{Ca}^{2+}$ fluxes indicating that PLC $\beta$ has a role in both pathways (Fig. 6A). However, the S100A9 null cells were less inhibited than the wildtype neutrophils at $1 \mu \mathrm{M}$ U73122. The inactive PLC analogue U73343 had no effect on either MIP-2 or FMLP signalling in wildtype or S100A9 null cells (Supplementary Fig. 2). PLC $\beta 2$ and PLC $\beta 3$ are the PLC isoforms transducing chemokine-induced $\mathrm{Ca}^{2+}$ flux in murine neutrophils [37] and Western blotting revealed that their levels were similar in wildtype and S100A9 null neutrophils (Fig. 6B). Attempts to assess the function of PLC $\beta$ by measuring $\mathrm{IP}_{3}$ production in response to agonist stimulation using commercially available reagents were unsuccessful, with $\mathrm{IP}_{3}$ levels being below the limits of detection using the maximum feasible number of neutrophils.

\subsection{An IP-mediated calcium release pathway is compromised in S100A9 null neutrophils}

The $\mathrm{IP}_{3}$ receptor is a ligand-operated ion-channel expressed on the $\mathrm{Ca}^{2+}$ stores in the endoplasmic reticulum, and the $\mathrm{IP}_{3}$-mediated $\mathrm{Ca}^{2+}$ release pathway is one of the major $\mathrm{Ca}^{2+}$ release pathways in non-excitable cells. An inhibitor of $\mathrm{IP}_{3} \mathrm{R}$ activity, 2-aminoethoxydiphenyl borate (2-APB) was examined at a dose of chemoattractant that gave equivalent $\mathrm{Ca}^{2+}$ flux responses in wildtype and S100A9 null neutrophils. 2-APB caused a large decrease in the MIP-2-induced $\mathrm{Ca}^{2+}$ flux response in the S100A9 null cells with only minimal effects on the wildtype cells (Fig. 7A). In 


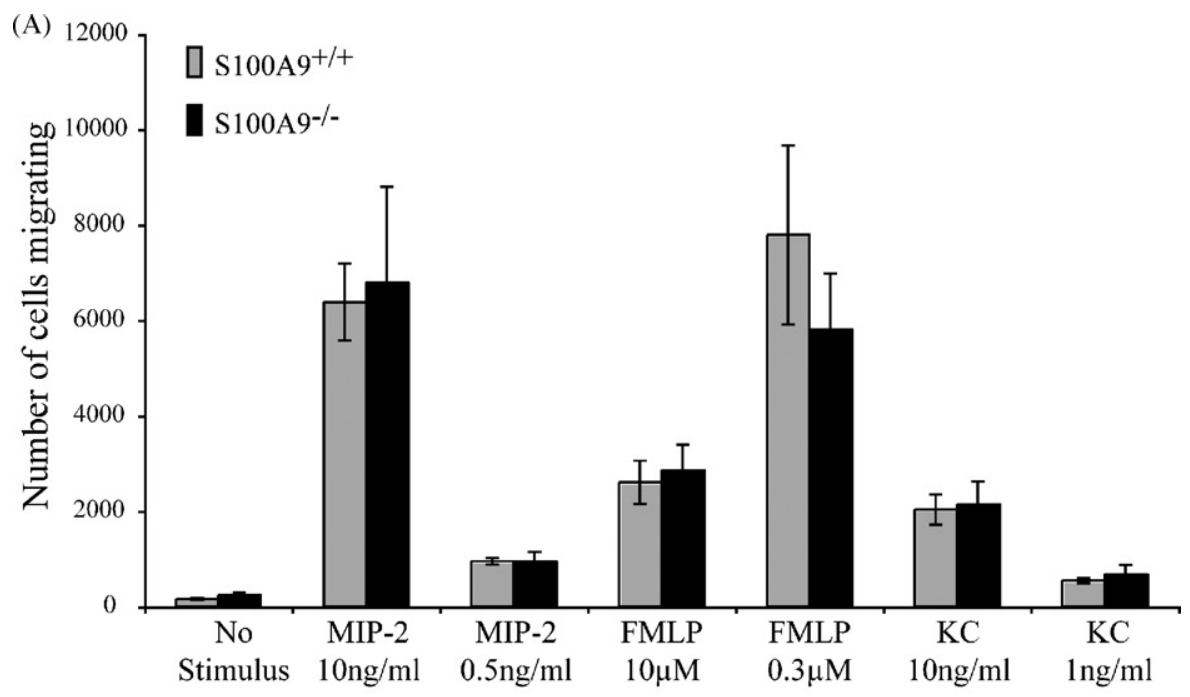

(B)
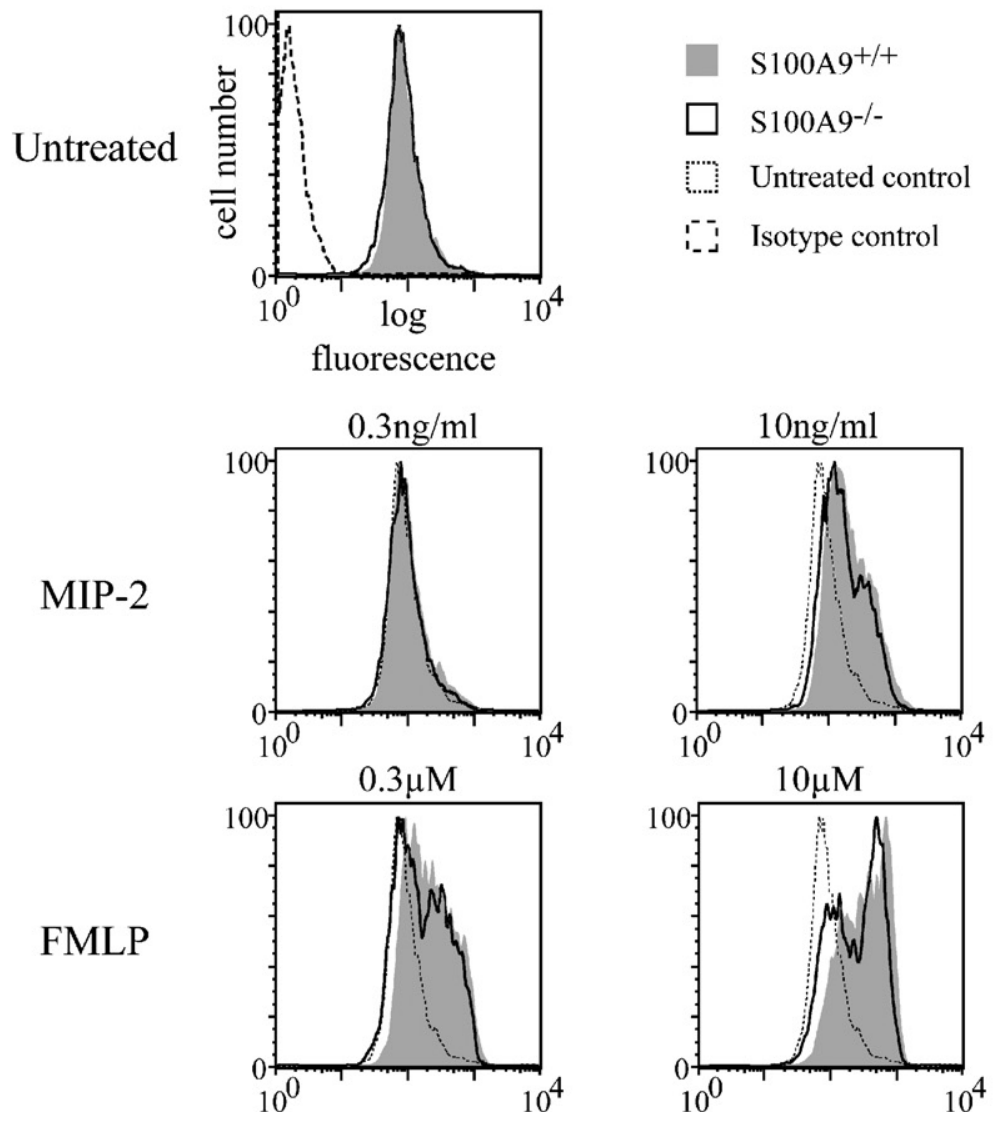

Fig. 3. Neutrophil chemotaxis and Mac-1 (CD11b/CD18) up-regulation in response to chemoattractants. (A) Migration of bone marrow neutrophils in response to MIP-2, FMLP and KC, at the concentrations shown, was evaluated using a Transwell model of chemotaxis. Data are expressed as the mean of three samples per genotype \pm S.D. and are representative of three independent experiments. (B) Bone marrow cells from S100A9 null and wildtype mice were stimulated with MIP-2 and FMLP at the concentrations shown for 30 mins at $37^{\circ} \mathrm{C}$. Cell surface Mac-1 expression on the neutrophils was examined by multi-colour flow cytometry. Data shown are for pooled samples from three mice per genotype and representative of three independent experiments.

contrast, there was no difference in the response of S100A9 null and wildtype neutrophils to FMLP. At lower doses of MIP-2 and FMLP, 2-APB completely inhibited the $\mathrm{Ca}^{2+}$ flux indicating that both stimulants are dependent on the $\mathrm{IP}_{3}$ receptor for $\mathrm{Ca}^{2+}$ release.
To check whether the possible lesion in the $\mathrm{IP}_{3}$ pathway could be due to differential expression of this receptor, Western blotting of a $98 \%$ pure neutrophil population was performed using a pan-IP $\mathrm{IP}_{3}$ receptor antibody. This revealed no gross difference in $\mathrm{IP}_{3}$ receptor expression (Fig. 7B). To 


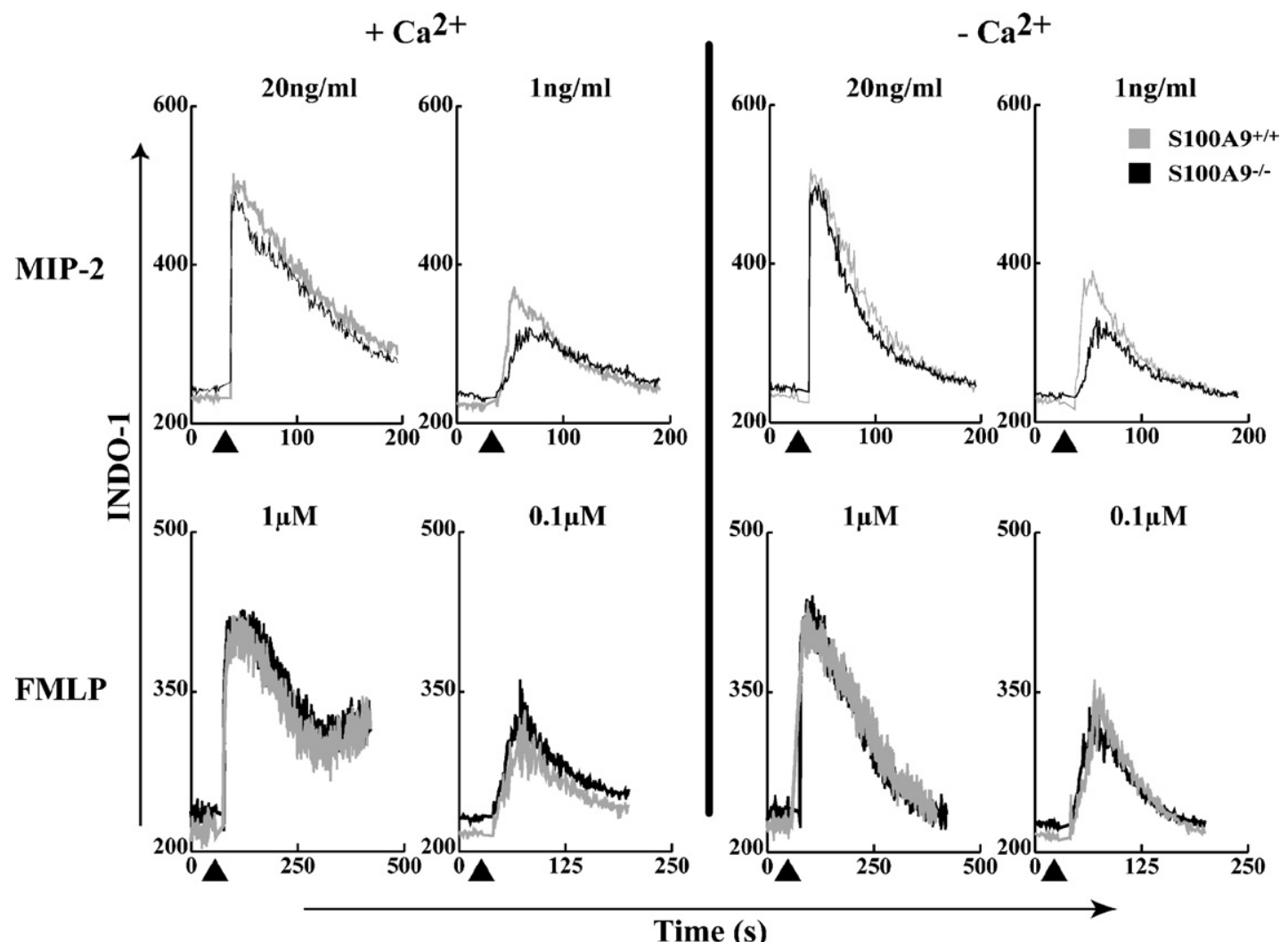

Fig. 4. The lesion in calcium signalling in S100A9 null neutrophils is in intracellular calcium release. Neutrophils from S100A9 null and wildtype mice were stimulated with MIP-2 and FMLP in the presence and absence of $1 \mathrm{mM}$ extracellular $\mathrm{Ca}^{2+}\left(\mathrm{Ca}^{2+}\right.$ removed by chelation with $4 \mathrm{mM}$ EGTA) and assessed for $\mathrm{Ca}^{2+}$ flux as described in Fig. 1. Data are representative of three independent experiments.

test if the function of the $\mathrm{IP}_{3}$ receptors was grossly normal, a homologue of $\mathrm{IP}_{3}$ in the form of a cell-permeable $\mathrm{IP}_{3}$-ester ( $\left.\mathrm{IP}_{3}-\mathrm{AM}\right)$ was used to stimulate the $\mathrm{IP}_{3}$ receptor directly [38]. The $\mathrm{IP}_{3}$ ester caused a sustained rise in cytosolic $\mathrm{Ca}^{2+}$ concentration at $10-20 \mu \mathrm{M}$ in both wildtype and S100A9 null neutrophils (Fig. 7C). This implies that the overall ability of the $\mathrm{IP}_{3}$ receptor to be activated by its ligand $\mathrm{IP}_{3}$ is normal in the S100A9 null neutrophils.

\subsection{Blocking DAG metabolism inhibits MIP-2}

signalling in S100A9 null neutrophils more potently than in wildtype neutrophils

Given the dis-regulation of PLC function observed in the S100A9 neutrophils, a role for diacylglycerol (DAG), a second product of PLC, was investigated. Treatment of S100A9 null cells with the cell permeable DAG mimetic, OAG, substantially reduced the MIP-2-induced $\mathrm{Ca}^{2+}$ flux compared with the wildtype response (Fig. 8A). There was no effect on the FMLP response in either type of neutrophil. To confirm an effect of DAG, DAG kinase, which converts DAG to phosphatidic acid (PA), was targeted using DAG Kinase Inhibitor II (R59949). This treatment inhibited the MIP-2-stimulated $\mathrm{Ca}^{2+}$ response completely at $50 \mu \mathrm{M}$ in S100A9 null neutrophils, while showing a more limited effect on wildtype neutrophils. There was also a limited effect of R59949 at this concentration on both types of neutrophil in the response to FMLP(Fig. 8B). These data indicate that enhancing DAG levels negatively affects chemoattractant signalling, with MIP-2 signalling in S100A9 neutrophils being particularly sensitive to increased levels of DAG. This effect is manifested only when DAG kinase is blocked, rather than DAG lipase, suggesting that DAG lipase activity is limited in murine neutrophils (Supplementary Fig. 3).

A major role of DAG is to activate $\mathrm{PKC}$ and it would be predicted that inhibition of PKC might reverse the lesion in the MIP-2-induced $\mathrm{Ca}^{2+}$ flux, if the downstream effector of DAG was PKC. Prior to stimulation with FMLP or MIP-2, the neutrophils were incubated with either $2 \mu \mathrm{M}$ BIM or $5 \mathrm{nM}$ calphostin C, which are both broad-spectrum PKC inhibitors. No effect of PKC inhibition was seen in the response to MIP-2 at any level (Supplementary Fig. 4). There was also no effect of PKC inhibition on the FMLP-induced $\mathrm{Ca}^{2+}$ flux in either wildtype or knockout cells. These results show that although the S100A9 null cells are sensitive to an elevation of DAG levels, this is not mediated through PKC.

\section{Discussion}

In this study the ability of S100A9 null neutrophils to generate $\mathrm{Ca}^{2+}$ signals initiated by inflammatory agonists has 
(A)

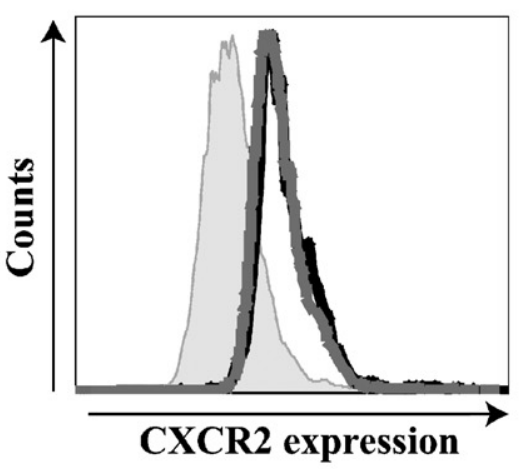

(B)

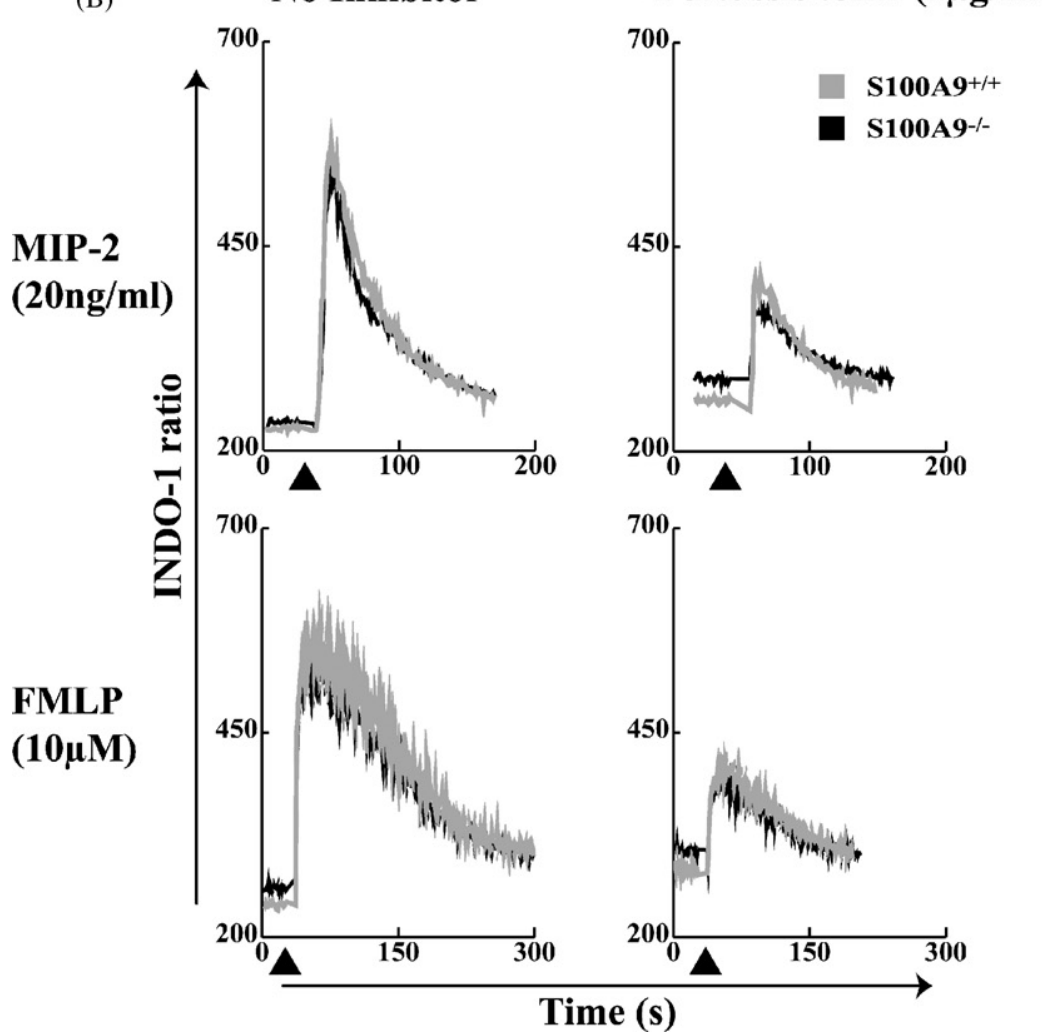

(C) AlF4-

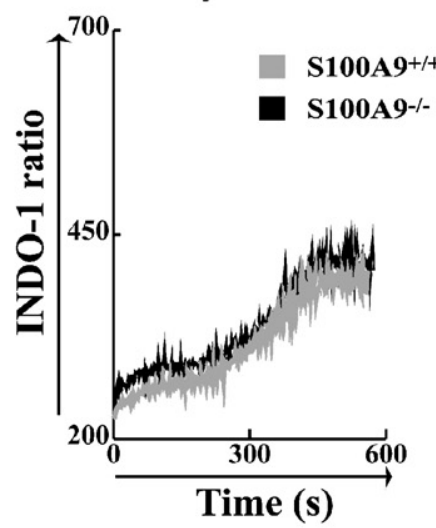

+ Pertussis toxin $(1 \mu \mathrm{g} / \mathrm{ml})$

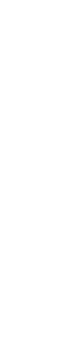




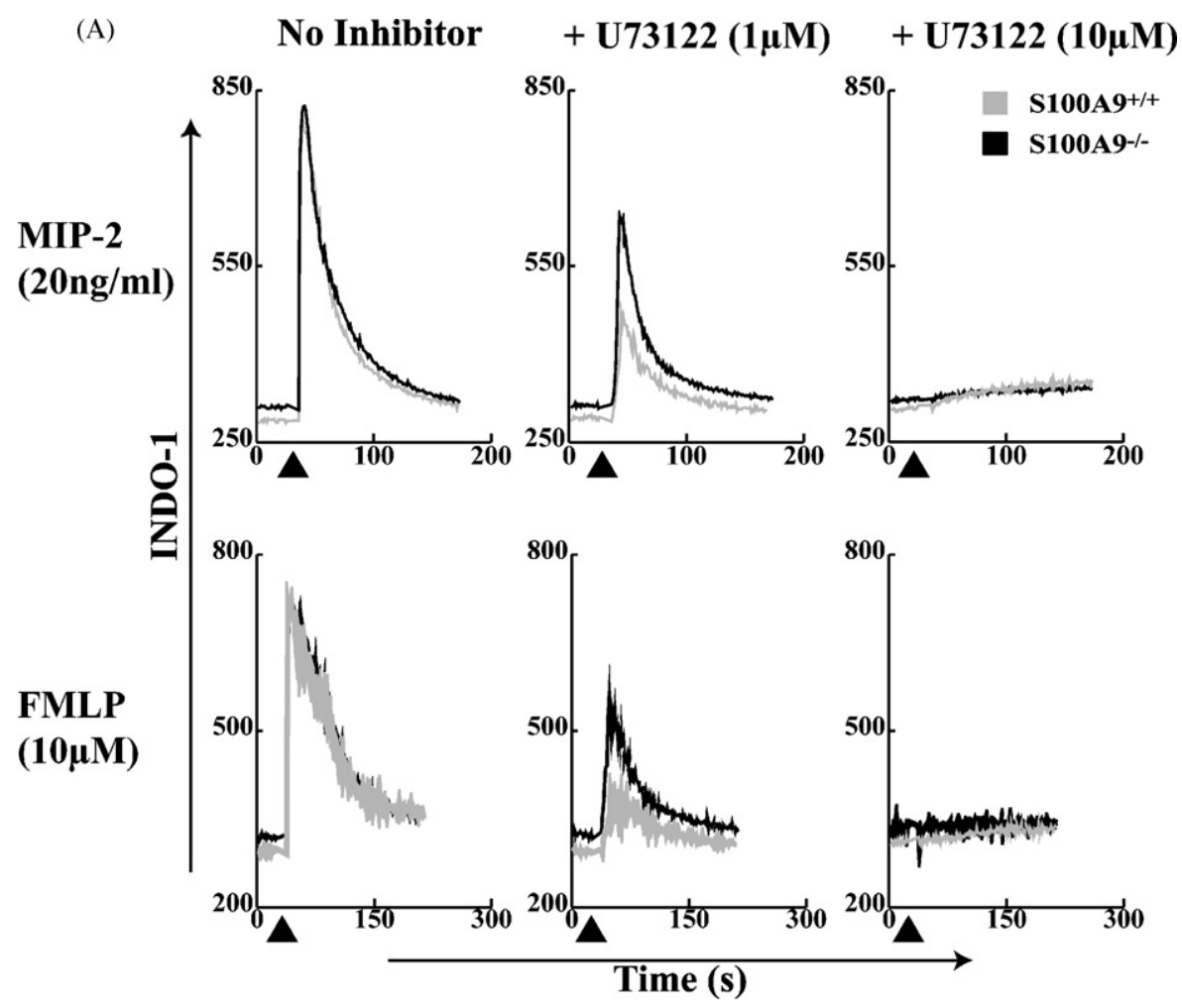

(B)

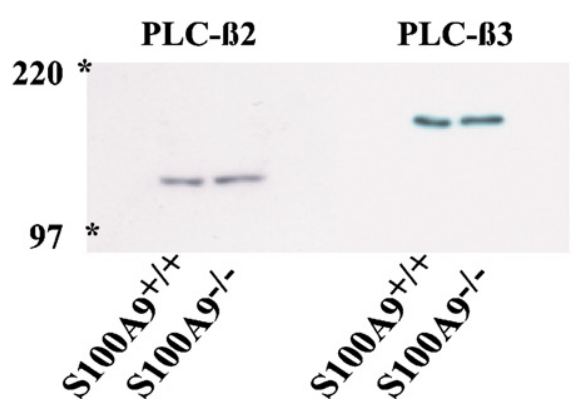

Fig. 6. Involvement of PLC $\beta$ in neutrophil chemoattractant-induced calcium signalling. (A) Bone marrow neutrophils were pre-incubated for $\geq 15$ min with 1-10 $\mathrm{M}$ U 73122 prior to stimulation with MIP-2 or FMLP. Data were assessed for $\mathrm{Ca}^{2+}$ flux as described in Fig. 1 and are representative of three independent experiments. (B) The expression of the PLC 32 and PLC $\beta 3$ isoforms was examined by Western blot analysis of neutrophil lysates as described in Section 2.

cytosolic protein, there was no obvious effect on the $\mathrm{Ca}^{2+}$ buffering potential of the cells, with the magnitude of the ionomycin response being identical in S100A9 null and wildtype neutrophils. Preliminary experiments to directly measure the $\mathrm{Ca}^{2+}$ buffering potential of the two cell types revealed no significant difference ( $\mathrm{S}$. Bolsover, unpublished data). It is of note that the small increase in baseline $\mathrm{Ca}^{2+}$ previously observed in the S100A9 null versus wildtype neutrophils appears to have no impact on these $\mathrm{Ca}^{2+}$ responses [23]. To date no up-regulation of any other proteins to compensate for any calcium-buffering function of S100A8/9 has been found either by 2D analysis comparing 175 proteins [23] or, as shown in this study, by RT-PCR evaluation of other S100 family members expressed in leukocytes. This would indicate that if S100A8/9 does have an important buffering function that it is compensated for in the S100A9 null neutrophils in manner that does not involve increased expression of another protein or that the S100A8/9 heterodimer truly has no calcium-buffering role. In contrast, when the S100-like protein calbindin D28k was deleted in mice, the peak magnitude of synaptically induced $\mathrm{Ca}^{2+}$ transients was enhanced by $80 \%$ in the mutant mice [39]. Calbindin D28k, like S100A8/9, is abundant, constituting $15 \%$ of total cellular protein in mature Purkinje cells [40], and it is this similarity of high expression levels that has lead to the assumption that the S100A8/9 heterodimer must be a major neutrophil cytosolic $\mathrm{Ca}^{2+}$ buffering protein. The use of thapsigargin, in the presence of $\mathrm{Ca}^{2+}$, showed that the Store Operated $\mathrm{Ca}^{2+}$ Entry profile for neutrophils was unaffected by the absence of S100A9. Thus, normal loading of the internal $\mathrm{Ca}^{2+}$ stores in the S100A9 null cells is also another key observation of normal $\mathrm{Ca}^{2+}$ homeostasis in these cells. Therefore, the 
(A)

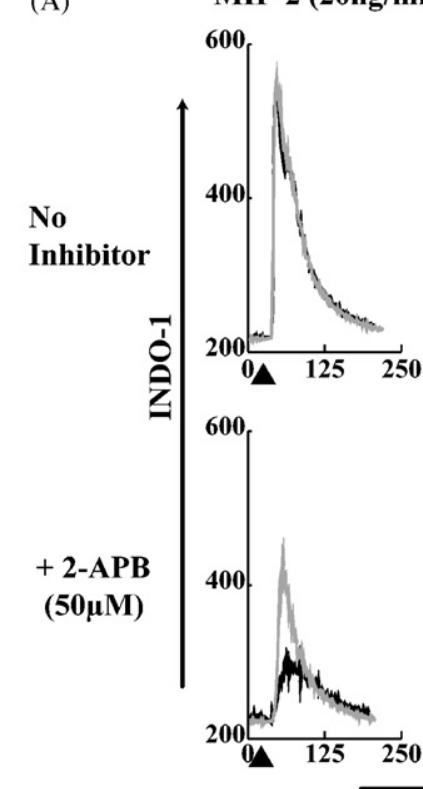

MIP-2 (2ng/ml)
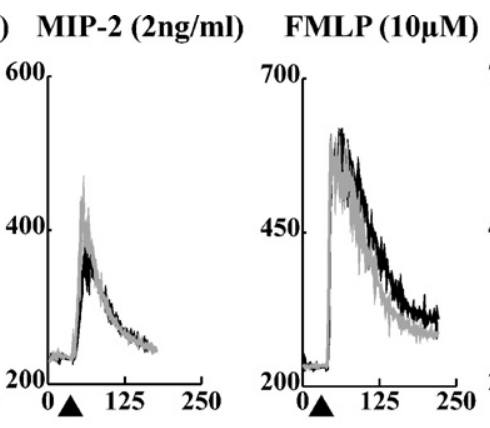

FMLP (1 $1 \mu \mathrm{M})$
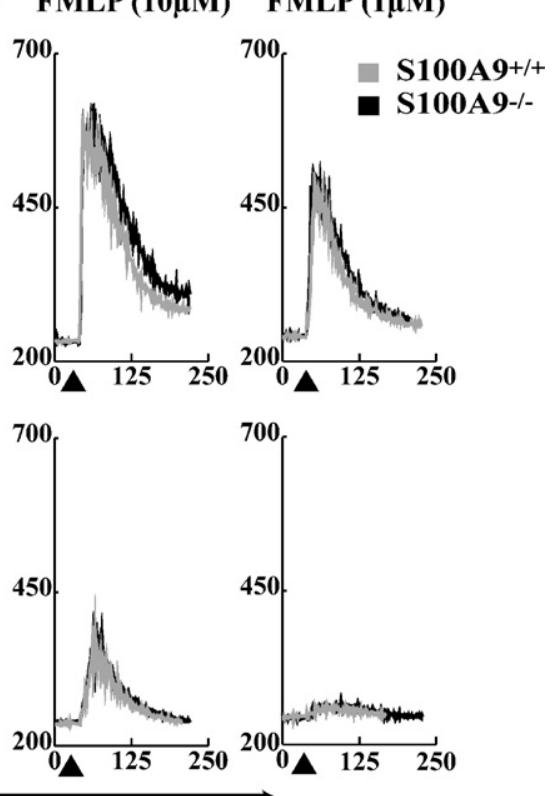

Time (s)

(B)

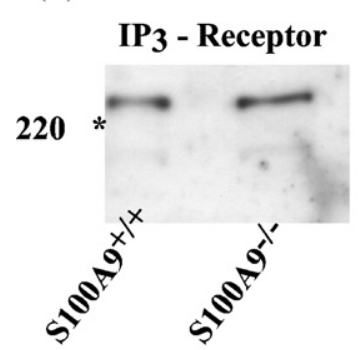

(C)

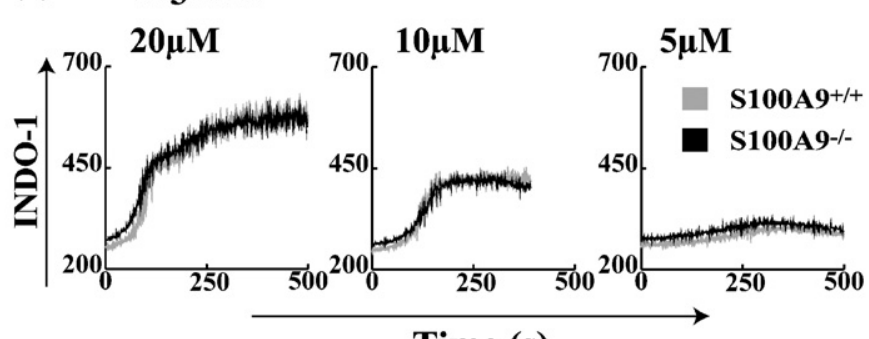

Time (s)

Fig. 7. Function of the $\mathrm{IP}_{3}$ receptor in wildtype and S100A9 null neutrophils. (A) Bone marrow leukocytes were exposed to 2 -APB (50 $\mu \mathrm{M}$ ) at time zero prior to stimulation with chemoattractant at the indicated time ( $\mathbf{\Lambda})$. (B) The expression of the $\mathrm{IP}_{3}$-receptor was examined by Western blot analysis of neutrophil lysate as described in Section 2. (C) Cells were incubated with a titration of $\mathrm{IP}_{3}-\mathrm{AM}$ for $10 \mathrm{~min}$ prior to observation of the Indo-1 signal for the time period shown. Data were assessed for $\mathrm{Ca}^{2+}$ flux as described in Fig. 1 and are representative of three independent experiments.

evidence from this present study is in keeping with the idea that $\mathrm{S} 100 \mathrm{~A} 8 / 9$ acts as a $\mathrm{Ca}^{2+}$ sensor participating in signal transduction.

Previously, we established that the S100A9 null neutrophils had a deficiency in ability to flux $\mathrm{Ca}^{2+}$ to the chemokine MIP-2 [23]. In this study, we show that the $\mathrm{Ca}^{2+}$ response is compromised to a broad range of chemoattractants such as chemokines of the CC and CXC type and other agonists C5a and PAF. Correlating the concentrations of chemoattractant used in this study to the levels to which neutrophils are exposed in vivo is not simple, as, for example, active chemokines are tethered onto the vascular endothelium. However, it should be noted that the serum concentration of MIP-2 in lipopolysaccharide-treated mice was reported to be in the nanogram range so comparable to the amounts tested in this study indicating their physiological relevance [41]. The S100A9 null neutrophils show a normal response to chemoattractant in terms of stimulation of chemotaxis or up-regulation of the integrin Mac-1. This indicates that the S100A9 null neutrophils are selectively compro- mised in their ability to perform a calcium flux in response to chemoattractant and not in all chemoattractant-induced responses. This is reminiscent of the phenotype of PLC $\beta 2 / 3$ null neutrophils, which have compromised chemoattractantinduced calcium signalling, but are not significantly impaired in their ability to chemotax to the same stimuli [37].

To dissect the lesion, MIP-2- and FMLP-mediated signalling was compared at various steps in the pathway leading to $\mathrm{Ca}^{2+}$ release from $\mathrm{Ca}^{2+}$ stores. The lesion is not at the level of chemokine receptor nor $\mathrm{G}$ protein signalling as the sensitivity of FMLP and chemokine CXCR1/2 receptor signalling to PTX shows normal coupling to the Gi pathway as expected [42-44]. However, a distinction between wildtype and S100A9 null neutrophils is evident at the level of PLC $\beta$ in that the sensitivity of wildtype neutrophils to the pharmacological inhibitor U73122 was greater than S100A9 null neutrophils suggesting dis-regulation at this level. Although both PLC $\beta 2$ and PLC $\beta 3$ isoforms are expressed at equivalent levels in wildtype and S100A9 null neutrophils (this study), PLC $\beta 2$ is the major active neutrophil specific isoform 
(A)

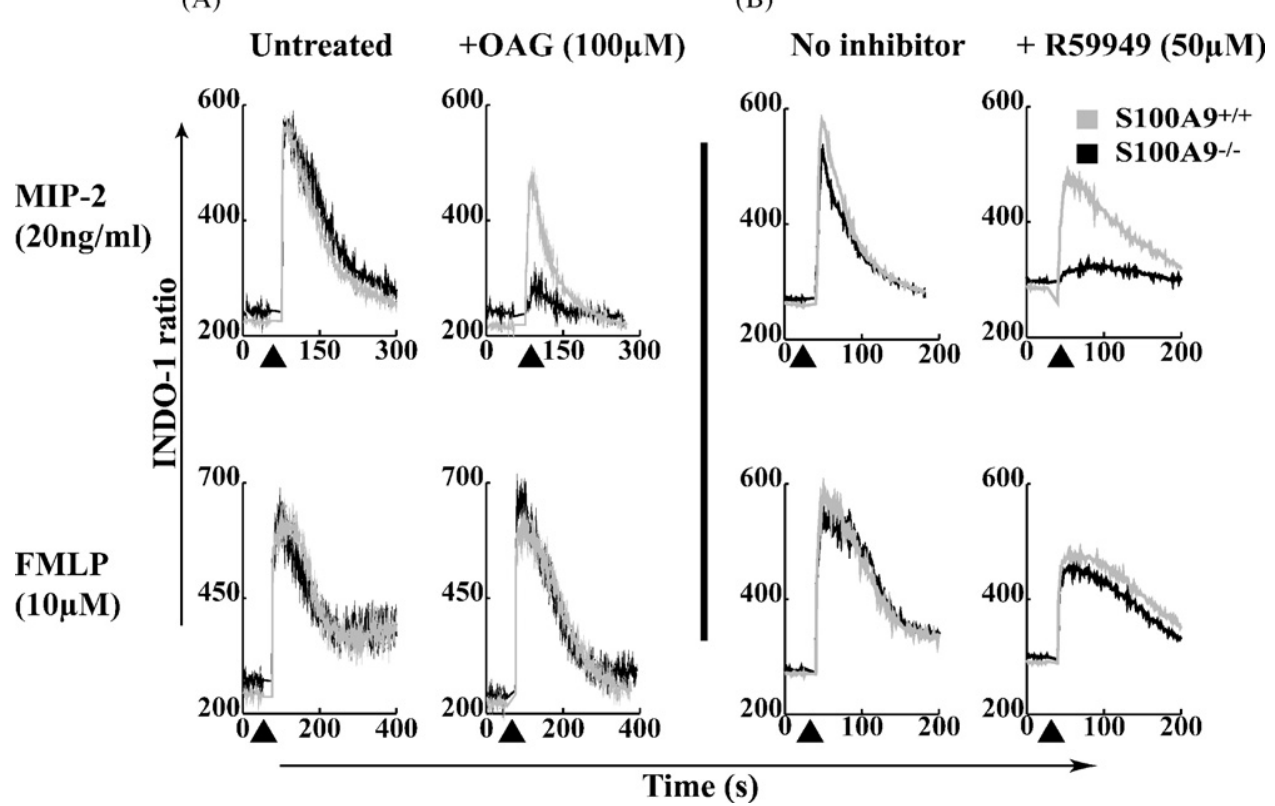

Fig. 8. Effect of alteration in DAG metabolism on neutrophil calcium signalling. (A) Bone marrow neutrophils were pre-incubated for $\geq 15$ min with $100 \mu \mathrm{M}$ OAG prior to stimulation with MIP-2 or FMLP. (B) Bone marrow neutrophils were pre-incubated for $\geq 15$ min with $50 \mu M$ DAG Kinase Inhibitor II prior to stimulation with MIP-2 or FMLP. Data were assessed for $\mathrm{Ca}^{2+}$ flux as described in Fig. 1 and are representative of three independent experiments.

[45]. In mice lacking the haematopoietic-specific PLC 32 isoform, neutrophil signalling by both IL-8 and FMLP is reduced, whereas in PLC $\beta 3$ null mice the reduction in $\mathrm{Ca}^{2+}$ flux is minimal $[37,45]$. However, in PLC $\beta 2 /$ PLC $\beta 3$ doubleknockout mice, signalling is completely abolished indicating a compensatory role for PLC $\beta 3$ in the absence of PLC $\beta 2$
$[37,45]$. Furthermore, the U73122 compound is reported to have greater potency against PLC $\beta 2$ than PLC $\beta 3$, as shown by the selective ability of U73122 to inhibit the hydrolysis of PIP2 by recombinant PLC $\beta$ isoforms [46]. One possibility is that in S100A9 null neutrophils, the signalling is coupled to PLC $\beta 3$ in preference to PLC $\beta 2$ thus being more

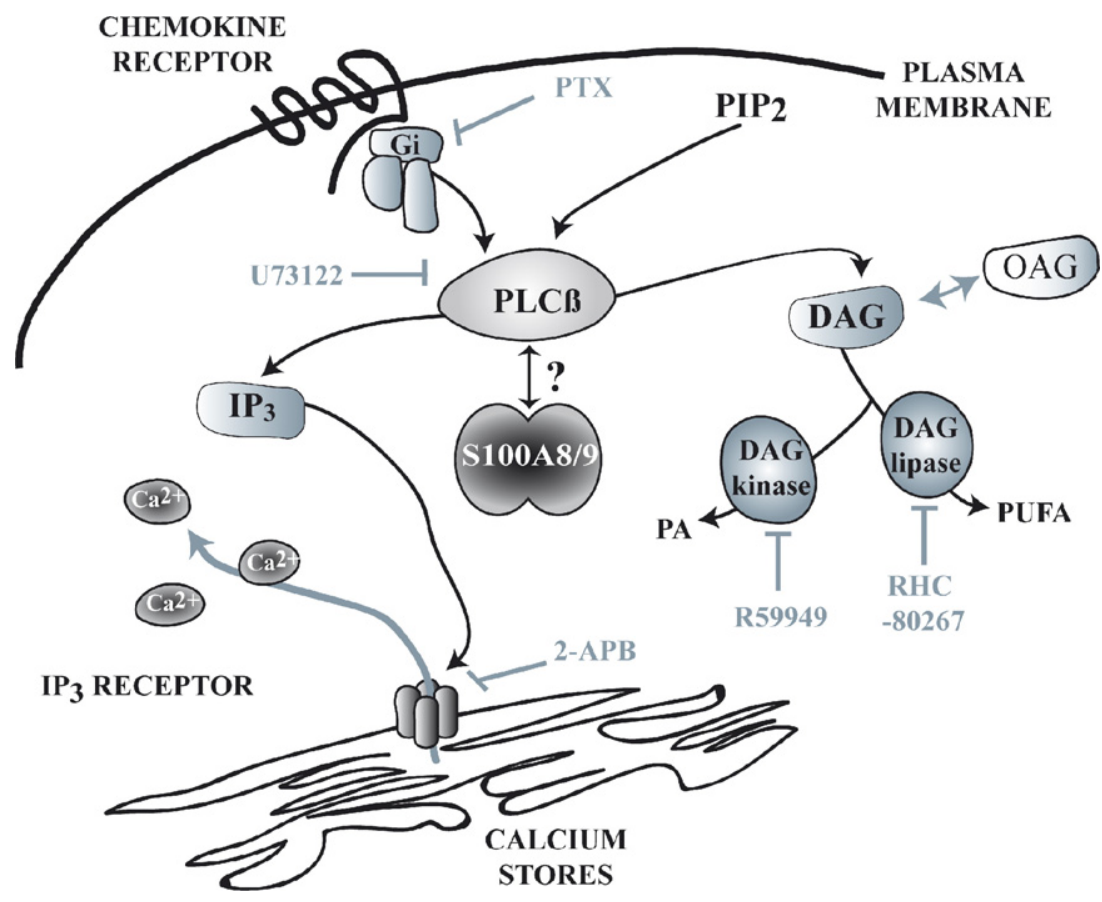

Fig. 9. Model of chemoattractant-induced calcium release. A model of the pathway leading from chemoattractant-induced signalling to IP ${ }_{3}$ receptor-mediated $\mathrm{Ca}^{2+}$ release from intracellular $\mathrm{Ca}^{2+}$ stores. The proposed site of action of S100A9 at the level of PLC $\beta$ is indicated as well as the target sites of the pharmacological tools used in this study. 
resistant to inhibition by U73122. A further possibility is that S100A8/9 may interact with PLC $\beta$ to modulate $\mathrm{IP}_{3}$ production. Due to limitations of the antibodies available, in our hands it was not possible to immunoprecipitate PLC $\beta 2$ or $\beta 3$ from murine neutrophils preventing further assessment of any direct interaction of S100A8/9. Complex formation between PLC and another $\mathrm{Ca}^{2+}$ binding protein, calmodulin (CaM) has been demonstrated. PLC $\beta 3 / \mathrm{CaM}$ positively affects muscarinic receptor stimulation of inositol phospholipid hydrolysis [47] and PLC $\delta 1$ interacts with CaM plus/minus the GTPase Ral1 to regulate the activity of this PLC [48].

$\mathrm{IP}_{3}$ is produced by the action of PLC in response to the chemoattractants and it is the mediator triggering the $\mathrm{IP}_{3} \mathrm{R}$ on the $\mathrm{Ca}^{2+}$ stores. An assessment of $\mathrm{IP}_{3}$ levels following stimulation would be an appropriate measure of the activity of the PLC $\beta$ isoforms. Rigorous attempts to measure neutrophil $\mathrm{IP}_{3}$ levels using purified cell populations were unfortunately not successful. We concluded that $\mathrm{IP}_{3}$ levels in stimulated mouse neutrophils were below the limits of the means of detection currently available to us. At the level of the $\mathrm{Ca}^{2+}$ stores, several studies have demonstrated the influence of $\mathrm{Ca}^{2+}$ binding proteins with ligand-gated $\mathrm{Ca}^{2+}$ release channels. The use of the $\mathrm{IP}_{3}$ ester, which directly stimulates $\mathrm{IP}_{3} \mathrm{R}$ activity [38] revealed no effect of the absence of S100A8/9 on $\mathrm{Ca}^{2+}$ release from the internal stores implying a lack of modulating effect of S100A8/9 on this receptor. Furthermore, attempts to co-immunoprecipitate $\mathrm{S} 100 \mathrm{~A} 8 / 9$ and the $\mathrm{IP}_{3}$ receptor using general and isotype specific antibodies were unsuccessful (data not shown).

There are several studies documenting $\mathrm{Ca}^{2+}$ binding protein ligands for the $\mathrm{IP}_{3}$ receptor that can either enhance or inhibit its activity. $\mathrm{CaM}$ in its $\mathrm{Ca}^{2+}$-unbound apo-CaM form inhibits $\mathrm{IP}_{3}$ binding to the $\mathrm{IP}_{3}$ receptor. In its $\mathrm{Ca}^{2+}$-bound state, $\mathrm{Ca}-\mathrm{CaM}$ facilitates the $\mathrm{Ca}^{2+}$-mediated inactivation of the receptor (reviewed in [49,50]). More recent studies have highlighted a modulatory effect of CaBP1 on $\mathrm{IP}_{3}$ receptor activation, with demonstrations of contrasting positive and negative roles for this protein on $\mathrm{IP}_{3}$ receptor activity. In one model, $\mathrm{Ca}^{2+}$ binding protein-1 (CaBP1) was shown to interact directly in a $\mathrm{Ca}^{2+}$-dependent manner with the $\mathrm{IP}_{3}$ receptor by co-immunoprecipitation and by the positive effect of CaBP1 on $\mathrm{IP}_{3}$ receptor opening as measured by individual channel patch clamping [51]. Alternatively, two studies have identified an inhibitory role for $\mathrm{CaBP} 1$ in that over-expressed $\mathrm{CaBP} 1$ has a negative effect on $\mathrm{IP}_{3}$ receptor activity following direct stimulation with $\mathrm{IP}_{3}$-ester [52] and also in response to purinergic receptor stimulation by physiological agonists [53]. Interestingly the S100 family member S100A1 interacts with a second class of $\mathrm{Ca}^{2+}$ release channels, which are the ryanodine receptor types I and II $[28,54]$. In the cardiomyocytes of S100A1-overexpressing transgenic mice, the sarcoplasmic reticulum, a major $\mathrm{Ca}^{2+}$ storage structure in excitable cells, has increased $\mathrm{Ca}^{2+}$ content [28]. In light of this data, it was of relevance that the lack of S100A8/9 had no effect on $\mathrm{Ca}^{2+}$ stores, further indicating that the lesion is not at this level.
In the S100A9 null neutrophils the signalling by FMLP and MIP-2 leading to $\mathrm{Ca}^{2+}$ flux is via PLC $\beta$ and the $\mathrm{IP}_{3}$ receptor, as both are sensitive to PLC $\beta$ inhibitor, U73122, and IP 3 receptor inhibitor, 2-APB. In spite of an abnormal response at the level of PLC $\beta$, no lesion in FMLP signalling was revealed, suggesting that a compensatory mechanism is in operation in S100A9 null neutrophils. However, a deficiency in $\mathrm{Ca}^{2+}$ signalling has been detected in signalling via $\mathrm{CC}$ and $\mathrm{CXC}$ chemokine and other receptors such as PAF and C5a. These findings indicate a situation where the basic $\mathrm{Ca}^{2+}$ release pathways used by both chemokine and the FMLP receptors are similar, but the regulation of these pathways is different. Our efforts have therefore also focussed on the chemokinesignalling pathway, which has been less well investigated. The MIP-2 response in S100A9 null neutrophils was particularly sensitive to increased DAG levels showing markedly reduced $\mathrm{Ca}^{2+}$ flux when exposed to DAG mimetic, OAG, and the DAG kinase inhibitor, which prevents DAG hydrolysis. As wildtype neutrophils only showed sensitivity at lower levels of chemokine (data not shown), a similar pathway to $\mathrm{Ca}^{2+}$ release is triggered in wildtype and S100A9 null neutrophils, but there is a shift in sensitivity to increased DAG levels in the latter cells. PKC is the best-identified downstream effector of DAG but blocking PKC activity in several ways had no impact on the chemokine response. A recent publication has highlighted a modulatory role for DAG in $\mathrm{IP}_{3}$-generated $\mathrm{Ca}^{2+}$ oscillations [55]. The findings differ from this present study in that DAG has a positive rather than a negative effect on the $\mathrm{Ca}^{2+}$ response and this effect is enhanced by inhibiting DAG lipase activity, again in contrast to the situation in murine neutrophils. However here also PKC appears not to have a role. Other downstream effectors are DAG are being identified $[56,57]$ and further effort will be needed to dissect what appears to be a novel regulatory role for DAG downstream of PLC $\beta$ activation.

Chemoattractants have been most thoroughly investigated in terms of their ability to drive the chemotaxis of cells such as neutrophils. Nevertheless we show that the ability to migrate and increase cell surface integrin expression in response to chemoattractants is intact in S100A9 null neutrophils, in spite of their compromised ability to flux $\mathrm{Ca}^{2+}$. Further insight into other roles of chemoattractants such as the chemokines are required to define the function of the $\mathrm{Ca}^{2+}$ flux in which S100A8/9 participates. However, in terms of chemoattractant signalling, this study has revealed an unexpected involvement S100A8/9 at the level of PLC $\beta$ in the generation of $\mathrm{Ca}^{2+}$ release by the $\mathrm{IP}_{3}$ receptor. Also highlighted is a strong modulatory role for DAG downstream of PLC $\beta$ particularly when the pathway is triggered by chemokine.

\section{Acknowledgements}

We thank Dr. Maurice Hallett, University of Cardiff and Drs. Alison McDowall and Peter Parker, CRUK London Research Institute for helpful comments on the manuscript. 


\section{Appendix A. Supplementary data}

Supplementary data associated with this article can be found, in the online version, at doi:10.1016/j.ceca. 2006.05.004.

\section{References}

[1] P.A. Hessian, J. Edgeworth, N. Hogg, MRP-8 and MRP-14, two abundant $\mathrm{Ca}(2+)$-binding proteins of neutrophils and monocytes, J. Leukoc. Biol. 53 (1993) 197-204.

[2] R. Donato, S100: a multigenic family of calcium-modulated proteins of the EF-hand type with intracellular and extracellular functional roles, Int. J. Biochem. Cell. Biol. 33 (2001) 637-668.

[3] C.W. Heizmann, G. Fritz, B.W. Schafer, S100 proteins: structure, functions and pathology, Front. Biosci. 7 (2002) d1356-d1368.

[4] J. Roth, T. Vogl, C. Sorg, C. Sunderkotter, Phagocyte-specific S100 proteins: a novel group of proinflammatory molecules, Trends Immunol. 24 (2003) 155-158.

[5] J. Edgeworth, M. Gorman, R. Bennett, P. Freemont, N. Hogg, Identification of $\mathrm{p} 8,14$ as a highly abundant heterodimeric calcium binding protein complex of myeloid cells, J. Biol. Chem. 266 (1991) 77067713.

[6] S. Teigelkamp, R.S. Bhardwaj, J. Roth, G. Meinardus-Hager, M. Karas, C. Sorg, Calcium-dependent complex assembly of the myeloic differentiation proteins MRP-8 and MRP-14, J. Biol. Chem. 266 (1991) 13462-13467.

[7] W. Nacken, C. Sopalla, C. Propper, C. Sorg, C. Kerkhoff, Biochemical characterization of the murine S100A9 (MRP14) protein suggests that it is functionally equivalent to its human counterpart despite its low degree of sequence homology, Eur. J. Biochem. 267 (2000) 560-565.

[8] P. Lemarchand, M. Vaglio, J. Mauel, M. Markert, Translocation of a small cytosolic calcium-binding protein (MRP-8) to plasma membrane correlates with human neutrophil activation, J. Biol. Chem. 267 (1992) 19379-19382.

[9] F. Guignard, J. Mauel, M. Markert, Phosphorylation of myeloid-related proteins MRP-14 and MRP-8 during human neutrophil activation, Eur. J. Biochem. 241 (1996) 265-271.

[10] W. Nacken, C. Sorg, C. Kerkhoff, The myeloid expressed EF-hand proteins display a diverse pattern of lipid raft association, FEBS Lett. 572 (2004) 289-293.

[11] J. Roth, F. Burwinkel, C. van den Bos, M. Goebeler, E. Vollmer, C. Sorg, MRP8 and MRP14, S-100-like proteins associated with myeloid differentiation, are translocated to plasma membrane and intermediate filaments in a calcium-dependent manner, Blood 82 (1993) 1875-1883.

[12] F. Burwinkel, J. Roth, M. Goebeler, U. Bitter, V. Wrocklage, E. Vollmer, A. Roessner, C. Sorg, W. Bocker, Ultrastructural localization of the S-100-like proteins MRP8 and MRP14 in monocytes is calciumdependent, Histochemistry 101 (1994) 113-120.

[13] J. Edgeworth, P. Freemont, N. Hogg, Ionomycin-regulated phosphorylation of the myeloid calcium-binding protein p14, Nature 342 (1989) 189-192.

[14] C. van den Bos, J. Roth, H.G. Koch, M. Hartmann, C. Sorg, Phosphorylation of MRP14, an S100 protein expressed during monocytic differentiation, modulates $\mathrm{Ca}(2+)$-dependent translocation from cytoplasm to membranes and cytoskeleton, J. Immunol. 156 (1996) 1247-1254.

[15] A. Rammes, J. Roth, M. Goebeler, M. Klempt, M. Hartmann, C. Sorg, Myeloid-related protein (MRP) 8 and MRP14, calcium-binding proteins of the S100 family, are secreted by activated monocytes via a novel, tubulin-dependent pathway, J. Biol. Chem. 272 (1997) 9496-9502.

[16] R.J. Passey, K. Xu, D.A. Hume, C.L. Geczy, S100A8: emerging functions and regulation, J. Leukoc. Biol. 66 (1999) 549-556.

[17] C. Ryckman, K. Vandal, P. Rouleau, M. Talbot, P.A. Tessier, Proinflammatory activities of S100: proteins S100A8, S100A9, and S100A8/A9 induce neutrophil chemotaxis and adhesion, J. Immunol. 170 (2003) 3233-3242.

[18] J. Roth, T. Vogl, C. Sunderkotter, C. Sorg, Chemotactic activity of S100A8 and S100A9, J. Immunol. 171 (2003) 5651.

[19] M.J. Robinson, P. Tessier, R. Poulsom, N. Hogg, The S100 family heterodimer, MRP-8/14, binds with high affinity to heparin and heparan sulfate glycosaminoglycans on endothelial cells, J. Biol. Chem. 277 (2002) 3658-3665.

[20] G. Srikrishna, D.K. Toomre, A. Manzi, K. Panneerselvam, H.H. Freeze, A. Varki, N.M. Varki, A novel anionic modification of $N$-glycans on mammalian endothelial cells is recognized by activated neutrophils and modulates acute inflammatory responses, J. Immunol. 166 (2001) 624-632.

[21] G. Srikrishna, K. Panneerselvam, V. Westphal, V. Abraham, A. Varki, H.H. Freeze, Two proteins modulating transendothelial migration of leukocytes recognize novel carboxylated glycans on endothelial cells, J. Immunol. 166 (2001) 4678-4688.

[22] D. Viemann, A. Strey, A. Janning, K. Jurk, K. Klimmek, T. Vogl, K. Hirono, F. Ichida, D. Foell, B. Kehrel, V. Gerke, C. Sorg, J. Roth, Myeloid-related proteins 8 and 14 induce a specific inflammatory response in human microvascular endothelial cells, Blood 105 (2005) 2955-2962.

[23] J.A. Hobbs, R. May, K. Tanousis, E. McNeill, M. Mathies, C. Gebhardt, R. Henderson, M.J. Robinson, N. Hogg, Myeloid cell function in MRP14 (S100A9) null mice, Mol. Cell. Biol. 23 (2003) 2564-2576.

[24] M.P. Manitz, B. Horst, S. Seeliger, A. Strey, B.V. Skryabin, M. Gunzer, W. Frings, F. Schonlau, J. Roth, C. Sorg, W. Nacken, Loss of S100A9 (MRP14) results in reduced interleukin-8-induced CD11b surface expression, a polarized microfilament system, and diminished responsiveness to chemoattractants in vitro, Mol. Cell. Biol. 23 (2003) 1034-1043

[25] M.J. Hunter, W.J. Chazin, High level expression and dimer characterization of the S100 EF-hand proteins, migration inhibitory factor-related proteins 8 and 14, J. Biol. Chem. 273 (1998) 12427-12435.

[26] I. Marenholz, C.W. Heizmann, G. Fritz, S100 proteins in mouse and man: from evolution to function and pathology (including an update of the nomenclature), Biochem. Biophys. Res. Commun. 322 (2004) $1111-1122$

[27] X.J. Du, T.J. Cole, N. Tenis, X.M. Gao, F. Kontgen, B.E. Kemp, J. Heierhorst, Impaired cardiac contractility response to hemodynamic stress in S100A1-deficient mice, Mol. Cell. Biol. 22 (2002) 2821 2829.

[28] P. Most, A. Remppis, S.T. Pleger, E. Loffler, P. Ehlermann, J. Bernotat, C. Kleuss, J. Heierhorst, P. Ruiz, H. Witt, P. Karczewski, L. Mao, H.A. Rockman, S.J. Duncan, H.A. Katus, W.J. Koch, Transgenic overexpression of the $\mathrm{Ca}^{2+}$-binding protein S100A1 in the heart leads to increased in vivo myocardial contractile performance, J. Biol. Chem. 278 (2003) 33809-33817.

[29] Z. Xiong, D. O'Hanlon, L.E. Becker, J. Roder, J.F. MacDonald, A. Marks, Enhanced calcium transients in glial cells in neonatal cerebellar cultures derived from S100B null mice, Exp. Cell. Res. 257 (2000) 281-289.

[30] S. Dewitt, I. Laffafian, M.B. Hallett, Phagosomal oxidative activity during beta2 integrin (CR3)-mediated phagocytosis by neutrophils is triggered by a non-restricted $\mathrm{Ca}^{2+}$ signal: $\mathrm{Ca}^{2+}$ controls time not space, J. Cell. Sci. 116 (2003) 2857-2865.

[31] K. Ayub, M.B. Hallett, $\mathrm{Ca}^{2+}$ influx shutdown during neutrophil apoptosis: importance and possible mechanism, Immunology 111 (2004) $8-12$.

[32] W. Schorr, D. Swandulla, H.U. Zeilhofer, Mechanisms of IL-8-induced $\mathrm{Ca}^{2+}$ signaling in human neutrophil granulocytes, Eur. J. Immunol. 29 (1999) 897-904.

[33] D. Wu, C.K. Huang, H. Jiang, Roles of phospholipid signaling in chemoattractant-induced responses, J. Cell. Sci. 113 (Pt 17) (2000) 2935-2940.

[34] Z.-Y. Lim, J.W. Thuring, A.R. Holmes, M. Manifava, N.T. Ktistakis, Synthesis and biologial evaluation of a PtdIns(4,5)P2 and a phos- 
phatidic acid affinity matrix, J. Chem. Soc. Perkin Trans. 1 (2002) 1067-1075.

[35] W. Li, C. Schultz, J. Llopis, R.Y. Tsien, Membrane-permeant esters of inositol polyphosphates, chemical synthesis and biological applications, Tetrahedron 53 (1997) 12017-12040.

[36] R.B. Henderson, J.A. Hobbs, M. Mathies, N. Hogg, Rapid recruitment of inflammatory monocytes is independent of neutrophil migration, Blood 102 (2003) 328-335.

[37] Z. Li, H. Jiang, W. Xie, Z. Zhang, A.V. Smrcka, D. Wu, Roles of PLCbeta2 and -beta3 and PI3Kgamma in chemoattractant-mediated signal transduction, Science 287 (2000) 1046-1049.

[38] C.M. Peppiatt, T.J. Collins, L. Mackenzie, S.J. Conway, A.B. Holmes, M.D. Bootman, M.J. Berridge, J.T. Seo, H.L. Roderick, 2-Aminoethoxydiphenyl borate (2-APB) antagonises inositol-1,4,5trisphosphate-induced calcium release, inhibits calcium pumps and has a use-dependent and slowly reversible action on store-operated calcium entry channels, Cell Calcium 34 (2003) 97-108.

[39] M.S. Airaksinen, J. Eilers, O. Garaschuk, H. Thoenen, A. Konnerth, M. Meyer, Ataxia and altered dendritic calcium signaling in mice carrying a targeted null mutation of the calbindin D28k gene, Proc. Natl. Acad. Sci. U.S.A. 94 (1997) 1488-1493.

[40] K.G. Baimbridge, J.J. Miller, C.O. Parkes, Calcium-binding protein distribution in the rat brain, Brain Res. 239 (1982) 519525.

[41] U. Deiters, P.F. Muhlradt, Mycoplasmal lipopeptide MALP-2 induces the chemoattractant proteins macrophage inflammatory protein 1alpha (MIP-1alpha), monocyte chemoattractant protein 1, and MIP-2 and promotes leukocyte infiltration in mice, Infect. Immun. 67 (1999) 3390-3398.

[42] S.R. Neves, P.T. Ram, R. Iyengar, G protein pathways, Science 296 (2002) 1636-1639.

[43] D. Wu, G.J. LaRosa, M.I. Simon, G protein-coupled signal transduction pathways for interleukin-8, Science 261 (1993) 101-103.

[44] H. Jiang, Y. Kuang, Y. Wu, A. Smrcka, M.I. Simon, D. Wu, Pertussis toxin-sensitive activation of phospholipase $\mathrm{C}$ by the $\mathrm{C} 5 \mathrm{a}$ and fMet-LeuPhe receptors, J. Biol. Chem. 271 (1996) 13430-13434.

[45] H. Jiang, Y. Kuang, Y. Wu, W. Xie, M.I. Simon, D. Wu, Roles of phospholipase $\mathrm{C}$ beta2 in chemoattractant-elicited responses, Proc. Natl. Acad. Sci. U.S.A. 94 (1997) 7971-7975.

[46] C. Hou, T. Kirchner, M. Singer, M. Matheis, D. Argentieri, D. Cavender, In vivo activity of a phospholipase $\mathrm{C}$ inhibitor, 1-(6-((17beta-3- methoxyestra-1,3,5(10)-trien - 17-yl)amino)hexyl)-1H-pyrrole-2,5dione (U73122), in acute and chronic inflammatory reactions, J. Pharmacol. Exp. Ther. 309 (2004) 697-704.

[47] J.S. McCullar, S.A. Larsen, R.A. Millimaki, T.M. Filtz, Calmodulin is a phospholipase C-beta interacting protein, J. Biol. Chem. 278 (2003) 33708-33713.

[48] R.S. Sidhu, R.R. Clough, R.P. Bhullar, Regulation of phospholipase C-delta1 through direct interactions with the small GTPase Ral and calmodulin, J. Biol. Chem. 280 (2005) 21933-21941.

[49] H.L. Roderick, M.D. Bootman, Bi-directional signalling from the InsP3 receptor: regulation by calcium and accessory factors, Biochem. Soc. Trans. 31 (2003) 950-953.

[50] N. Nadif Kasri, G. Bultynck, I. Sienaert, G. Callewaert, C. Erneux, L. Missiaen, J.B. Parys, H. De Smedt, The role of calmodulin for inositol1,4,5-trisphosphate receptor function, Biochim. Biophys. Acta 1600 (2002) 19-31.

[51] J. Yang, S. McBride, D.O. Mak, N. Vardi, K. Palczewski, F. Haeseleer, J.K. Foskett, Identification of a family of calcium sensors as protein ligands of inositol trisphosphate receptor $\mathrm{Ca}(2+)$ release channels, Proc. Natl. Acad. Sci. U.S.A. 99 (2002) 7711-7716.

[52] N.N. Kasri, A.M. Holmes, G. Bultynck, J.B. Parys, M.D. Bootman, K. Rietdorf, L. Missiaen, F. McDonald, H. De Smedt, S.J. Conway, A.B. Holmes, M.J. Berridge, H.L. Roderick, Regulation of InsP3 receptor activity by neuronal $\mathrm{Ca}^{2+}$-binding proteins, EMBO J. 23 (2004) 312-321.

[53] L.P. Haynes, A.V. Tepikin, R.D. Burgoyne, Calcium-binding protein 1 is an inhibitor of agonist-evoked, inositol-1,4,5-trisphosphate-mediated calcium signaling, J. Biol. Chem. 279 (2004) 547-555.

[54] S. Treves, E. Scutari, M. Robert, S. Groh, M. Ottolia, G. Prestipino, M. Ronjat, F. Zorzato, Interaction of S100A1 with the $\mathrm{Ca}^{2+}$ release channel (ryanodine receptor) of skeletal muscle, Biochemistry 36 (1997) 11496-11503.

[55] C. Hisatsune, K. Nakamura, Y. Kuroda, T. Nakamura, K. Mikoshiba, Amplification of $\mathrm{Ca}^{2+}$ signaling by diacylglycerolmediated inositol-1,4,5-trisphosphate production, J. Biol. Chem. 280 (2005) 11723-11730.

[56] G.M. Springett, H. Kawasaki, D.R. Spriggs, Non-kinase secondmessenger signaling: new pathways with new promise, Bioessays 26 (2004) 730-738.

[57] K. Goto, H. Kondo, Functional implications of the diacylglycerol kinase family, Adv. Enzyme Regul. 44 (2004) 187-199. 